\title{
A inconstitucionalidade da instituição de contribuição previdenciária para servidores inativos*
}

\section{The unconstitutionality of the social security contribution for retirees in the public service}

\author{
Emerson Gabardo** \\ Thiago Priess Valiati***
}

\section{RESUMO}

O artigo analisa a constitucionalidade da política pública de cobrança de contribuição previdenciária dos servidores inativos no Brasil. Inicialmente, são elencados seis argumentos para a sustentação da proposição de inconstitucionalidade: o dever de obediência ao ato jurídico perfeito

* Artigo recebido em 4 de maio de 2015 e aprovado em 27 de julho de 2015. DOI: http://dx.doi. org/10.12660/rda.v270.2015.58743

* Universidade Federal do Paraná e Pontifícia Universidade Católica do Paraná, Curitiba, Paraná, Brasil. E-mail: e.gab@uol.com.br.

Professor de direito Administrativo na Universidade Federal do Paraná. Professor de direito econômico da Pontifícia Universidade Católica do Paraná. Pós-doutor em direito público comparado pela Fordham University School of Law. Conselheiro estadual da OABPR.

*** Universidade Federal do Paraná, Curitiba, Paraná, Brasil. E-mail: thiago@grlg.adv.br. Mestrando em direito do estado na Universidade Federal do Paraná. Especialista em direito administrativo pelo Instituto de Direito Romeu Felipe Bacellar. Advogado. 
e ao direito adquirido; a aplicação do princípio da confiança, da boa-fé e da teoria da perda de uma chance; a vedação ao confisco e o caráter alimentar das prestações previdenciárias; a proibição da tributação sem causa e a ausência de contraprestação por parte do Estado; a vedação ao bis in idem; e a prevalência da solidariedade em favor dos vulneráveis e o princípio da proibição do retrocesso social. Finalmente, o trabalho destaca a possibilidade de inconstitucionalidade formal da contribuição dos servidores inativos quando não estão presentes dois requisitos: a necessidade de emenda à Constituição do Estado para a instituição da cobrança; e a obediência ao devido processo legislativo.

\section{PALAVRAS-CHAVE}

Previdência social - servidores públicos - princípio da solidariedade social - políticas públicas - princípio da segurança jurídica

\section{ABSTRACT}

The article analyzes the constitutionality of public policy for social security contribution collection of retirees in Brazil. At first, six arguments to support the unconstitutionality proposition are listed: The duty of obedience to perfect legal acts and vested rights; the application of the principle of trust, good faith, and loss of chance theory; the sealing of confiscation and the feed character of social security benefits; the tax prohibition without cause and the lack of consideration by the State; the sealing to "bis in idem"; and the prevalence of solidarity for the vulnerable and principle of prohibition to social regression. Finally, the paper highlights the possibility of formal unconstitutionality of retiree contribution collection when two requirements are not present: the need of an amendment to the State Constitution for the establishment of retiree contribution collection; and obedience to the due process of law.

\section{KEYWORDS}

Social security - civil servants - principle of social solidarity - public policy - principle of legal certainty 


\section{Introdução}

A previdência dos servidores públicos no Brasil é tradicionalmente uma matéria de competência local (ou seja, cada entidade estabelece seu regime, respeitados apenas alguns princípios fundamentais estabelecidos pela Constituição Federal). A regra, inclusive, era a não contribuição para a aposentadoria (em geral os descontos previdenciários destinavam-se exclusivamente ao futuro pagamento de pensão e outros benefícios). Até 1988 essa situação não era problemática, considerando que a maioria dos servidores era celetista. Todavia, o quadro foi revertido na década de 1990. Nesse contexto, o governo brasileiro entendeu que era necessária uma alteração no modelo de política pública então aplicada. Foi então que a Emenda Constitucional no 03/1993 alterou o sistema, impondo um novo regime em que a aposentadoria passou a ser um verdadeiro "benefício", portanto, de caráter contributivo (antes era um "direito" fruto da condição subjetiva do servidor). ${ }^{1}$

Até então nem se cogitava extensão da contribuição aos inativos. Todavia, logo essa demanda entrou em pauta e o governo federal decidiu, por meio de legislação infraconstitucional (Lei no 9.983/1999), impor tal desconto. Todavia, esse diploma legal foi declarado inconstitucional pelo Supremo Tribunal Federal (ADIn no 2.010). No referido julgado, o STF entendeu ser inconstitucional a instituição de contribuição previdenciária aos pensionistas e inativos, em razão de o caput do art. 40 da Constituição Federal, na oportunidade, utilizar a expressão "servidor ocupante de cargo efetivo". Assim, o princípio do equilíbrio financeiro-atuarial, que garantiria a solvabilidade da previdência social, por óbvio, era direcionado tão somente para os servidores ativos. Outros dois fundamentos essenciais utilizados no julgamento da ADIn no 2.010 para a declaração de inconstitucionalidade da cobrança dos inativos foram os princípios da contributividade e da retributividade direta.

Todavia, por intermédio da Emenda Constitucional no 41/2003, o Congresso Nacional procurou considerar os fundamentos indicados pelo STF no julgamento da ADIn no 2.010, de forma a contornar os impasses que o julgamento anterior havia instituído à cobrança da contribuição sobre os inativos. Destarte, produziu-se na oportunidade a polêmica matriz constitucional exigida para a instituição da cobrança dos inativos com a introdução,

1 PACHECO FILHO, Calino; WINCKLER, Carlos Roberto. Reforma na previdência: o ajuste no serviço público. Indic. Econ. FEE, Porto Alegre, v. 32, n. 4, p. 221-248, mar. 2005. 
no caput do art. 40 do diploma constitucional, da expressão "e inativos", além do princípio da solidariedade social.

Posteriormente, com a instituição da necessária matriz constitucional para a cobrança dos inativos, o STF voltou a analisar a questão na ADIn no 3.105, tendo nessa ocasião concluído pela constitucionalidade da cobrança, contrariamente ao que havia sido decidido anteriormente na ADIn no 2.010. Os argumentos centrais dos votos que compuseram a maioria do julgamento foram a presença de um suposto dever de solidariedade geral (inclusive dos servidores inativos) para a preservação da previdência social. Mas não há dúvida de que o pano de fundo do julgamento foi o déficit crônico do sistema previdenciário.

Em que pese o entendimento firmado pelo STF na ADIn no 3.105, vários estados da federação não a instituíram. O estado do Paraná, por exemplo, passou mais de uma década sem cobrar a referida contribuição. O governo estadual, à época da decisão, tendo em vista a autonomia do ente federativo para regular seu próprio regime de previdência, entendeu que seu sistema previdenciário poderia permanecer sem a instituição da cobrança. Tal fato não passou despercebido pela União, que passou a pressionar fortemente os entes federados para que efetivassem o desconto (inclusive ameaçando-os com a suspensão de repasses voluntários).

Mais recentemente, e provavelmente devido à intensificação da crise financeira a partir da segunda década do século XXI (que afetou de forma intensa alguns entes federativos já endividados e dependentes de commodities), os estados da federação acabaram se rendendo. Desse modo, e em que pese a expectativa criada aos aposentados em alguns casos por mais de uma década, a cobrança previdenciária dos inativos foi instituída. Mesmo os servidores que se aposentaram antes dessa alteração do sistema passaram a ser cobrados. Foi ignorada, portanto, a justa expectativa de que essa cobrança não ocorreria em âmbito estadual, em face da autonomia do ente federativo (em alguns casos a instituição ocorreu por emenda à Constituição estadual, como em São Paulo; em outros, apenas por lei, como no Paraná). ${ }^{2}$

2 A título exemplificativo, no Paraná, a cobrança decorre da edição recente da Lei no 18.370/2014, mediante o acréscimo do $\S 6^{\circ}$ ao art. 15 da Lei Estadual no 17.435/2012. Com efeito, por meio do aludido diploma legal foi instituída no âmbito do estado do Paraná a contribuição previdenciária para os aposentados e pensionistas: "os aposentados e os pensionistas do Estado, inclusive os de suas Autarquias e Fundações, do Poder Judiciário, Poder Legislativo, Tribunal de Contas, Ministério Público e Polícia Militar, contribuirão com 11\% (onze por 
A partir desse contexto, a discussão parece merecer uma nova reflexão. No presente artigo será questionada a constitucionalidade (formal e material) da cobrança previdenciária dos servidores inativos (e pensionistas). Em um primeiro momento, será discutida a constitucionalidade material da cobrança. Nesse passo, analisar-se-ão as garantias do ato jurídico perfeito e do direito adquirido contra a Emenda Constitucional noำ1/2003, o princípio da confiança e da boa-fé dos servidores inativos, o cenário de confisco em relação ao caráter alimentar das prestações previdenciárias, a configuração de tributação sem causa ao instituir uma cobrança sem respectiva contraprestação, a ofensa ao princípio do ne bis in idem. E, finalmente, será analisada a possibilidade da violação ao princípio da proibição do retrocesso social, bem como a inversão da lógica da solidariedade previdenciária através da criação de um ônus sobre vulneráveis. Em um segundo momento serão destacados os aspectos formais em termos de verificação constitucional. A contribuição dos inativos foi instituída em alguns casos, como no Paraná, sem a observância do devido processo legislativo e sem a necessária emenda à Constituição estadual, diferentemente do que ocorreu no âmbito federal e em outros estados da federação.

\section{As inconstitucionalidades materiais na contribuição previdenciária dos inativos}

A cobrança da contribuição previdenciária sobre os servidores inativos parece constituir evidente violação aos direitos individuais, sendo manifestamente inconstitucional do ponto de vista material. Com efeito, serão analisadas, a partir de agora, as garantias do ato jurídico perfeito e do direito adquirido contra a Emenda Constitucional no $41 / 2003$, o princípio da confiança e da boa-fé dos servidores inativos, o cenário de confisco em relação ao caráter alimentar das prestações previdenciárias, a configuração de tributação sem causa ao instituir uma cobrança sem a respectiva contraprestação, a ofensa ao princípio do ne bis in idem e, finalmente, a violação ao princípio da proibição do retrocesso social e a inversão da lógica da solidariedade previdenciária por meio da criação de um ônus sobre os aposentados e pensionistas (por natureza, sujeitos vulneráveis).

cento), incidentes sobre o valor da parcela dos proventos de aposentadoria e pensões que supere o limite máximo estabelecido para os benefícios do regime geral de previdência social". 


\subsection{Do ato jurídico perfeito e direito adquirido contra a Emenda Constitucional no 41/2003 (art. 5o, inciso XXXVI, da Constituição Federal)}

$\mathrm{O}$ art. 5ำ, inciso XXXVI, da Constituição Federal dispõe que "a lei não prejudicará o direito adquirido, o ato jurídico perfeito e a coisa julgada". Para Romeu Felipe Bacellar Filho, o referido dispositivo discute a respeito da proteção de direitos mediante a imutabilidade das relações juridicamente já consolidadas, garantindo o indivíduo contra o advento de lei posterior. ${ }^{3}$ Nesse cenário, o ato jurídico perfeito é identificado em consonância com a lei do tempo em que se consolidou a situação jurídica do sujeito. Segundo Regina Maria Macedo Nery Ferrari, quando se fala em ato jurídico perfeito, se está diante de uma questão puramente formal, isto é, da realização em concreto do conteúdo da norma em vigência durante o momento de sua realização, verificando-se o cumprimento de todas as exigências legais à época de sua vigência. ${ }^{4}$ Ou seja, trata-se de um direito subjetivo não só incorporado, mas já efetivamente exercido por seu titular.

Por sua vez, o cumprimento de requisitos para o futuro exercício de direitos gera o direito adquirido. $\mathrm{O}$ desrespeito em um momento posterior dos direitos subjetivos adquiridos no contexto de uma norma já não mais em vigor prejudicaria, segundo Regina Ferrari, o interesse de seus titulares e instauraria uma situação de desordem social. ${ }^{5}$ A irretroatividade da norma em face aos direitos incorporados, mas ainda não exercidos pelo seu titular (às vezes pela falta de alguma condição futura), é uma garantia constitucional de natureza pétrea.

Todavia, o STF, na oportunidade de julgamento da questão, parece não ter se demonstrado muito sensível a tal garantia constitucional. A controvérsia, in casu, consiste no confronto de uma situação de direito adquirido ou ato jurídico perfeito a partir da edição de emenda constitucional.

3 BACELLAR FILHO, Romeu Felipe. A estabilidade do ato administrativo criador de direitos à luz dos princípios da moralidade, da segurança jurídica e da boa-fé. AEC - Revista de Direito Administrativo \& Constitucional, Belo Horizonte, ano 10, n. 40, 2010. Disponível em: <www. editoraforum.com.br/bid/bidConteudoShow.aspx?idConteudo=67732>. Acesso em: 7 jul. 2010.

4 FERRARI, Regina Maria Macedo Nery. O ato jurídico perfeito e a segurança jurídica no controle de constitucionalidade. In: ROCHA, Carmen Lúcia Antunes (Coord.). Constituição e segurança jurídica: direito adquirido, ato jurídico perfeito e coisa julgada. Estudos em homenagem a José Paulo Sepúlveda Pertence. Belo Horizonte: Fórum, 2004. p. 226.

5 Ibid. 
Isto é, se o termo "lei" indicado no art. 5ํ, XXXVI, do texto constitucional também abarcaria a edição de emendas ao texto da Constituição, possuindo, portanto, um significado mais amplo ou, por outro lado, se deveria restringirse à legislação infraconstitucional, possuindo um significado restrito. Nesse tocante, segundo Bacellar Filho, despontam dois entendimentos possíveis: o que defende que o poder de reforma do texto constitucional está estritamente condicionado a respeitar todo e qualquer direito adquirido e ato jurídico perfeito; e o entendimento de que não há direito adquirido ou ato jurídico perfeito em face da Constituição, por meio do qual se alega que o poder de reforma constitucional não encontra nenhum tipo de limitação. ${ }^{6}$

O STF, por meio do julgamento da ADIn no 3.105 , afirmou o segundo entendimento, isto é, que a garantia do direito adquirido não pode configurar um limite ao poder de reforma constitucional, sustentando que a expressão "lei", inserida no art. 5o, XXXVI, deve ser entendida em sua concepção restrita. Apenas o legislador infraconstitucional, dessa forma, estaria submetido a respeitar o direito adquirido e o ato jurídico perfeito. ${ }^{7}$ Nesse sentido, Gilmar Ferreira Mendes salientou que "o princípio constitucional do direito adquirido

6 Romeu Felipe Bacellar Filho, A estabilidade do ato administrativo criador de direitos à luz dos princípios da moralidade, da segurança jurídica e da boa-fé, op. cit., passim.

7 Segundo Gilmar Ferreira Mendes: “assentou-se na jurisprudência do Supremo Tribunal Federal, pois, que a proteção ao direito adquirido e ao ato jurídico perfeito não obstava à modificação ou à supressão de determinado instituto jurídico. Em acórdão proferido no RE 94.020, de 4-11-1981, deixou assente a Excelsa Corte, pela voz do Ministro Moreira Alves que '(...) em matéria de direito adquirido vigora o princípio - que este Tribunal tem assentado inúmeras vezes - de que não há direito adquirido a regime jurídico de um instituto de direito. Quer isso dizer que, se a lei nova modificar o regime jurídico de determinado instituto de direito (como é o direito de propriedade, seja ela de coisa móvel ou imóvel, ou de marca), essa modificação aplica-se de imediato. Esse entendimento foi reiterado pelo Supremo Tribunal Federal em tempos mais recentes. Em decisão proferida no RE 226.855, a Corte reconheceu a natureza institucional do FGTS, afirmando que é de aplicar-se a ele a firma jurisprudência da Corte no sentido de que não há direito adquirido a regime jurídico" (MENDES, Gilmar Ferreira. Comentários ao artigo 5o, inciso XXXVI. In: CANOTILHO, J. J. Gomes; MENDES, Gilmar Ferreira; SARLET, Ingo Wolfgang; STRECK, Lenio Luiz (Coord.). Comentários à Constituição do Brasil. São Paulo: Saraiva; Almedina, 2013. p. 369). Nestes termos, segundo a jurisprudência do Supremo: "Magistrado. Incidência imediata da proibição contida no artigo 114, I, da Constituição Federal na redação dada pela Emenda Constitucional nº 7/77. - Não há direito adquirido contra texto constitucional, resulte ele do Poder Constituinte originário, ou do Poder Constituinte derivado. Precedentes do STF. Recurso extraordinário conhecido e provido" (STF. Recurso Extraordinário no 94.414-SP. Rel. min. Moreira Alves. RTJ, 114/237, RDA 160/144, j. em 13.2.1985). “(...) A supremacia jurídica das normas inscritas na Carta Federal não permite, ressalvadas as eventuais exceções proclamadas no próprio texto constitucional, que contra elas seja invocado o direito adquirido. Doutrina e jurisprudência" (STF - Ação Direta de Inconstitucionalidade 248 RJ, relator: CELSO DE MELLO, data de julgamento: 18/11/1993, TRIBUNAL PLENO, data de publicação: DJ 8-4-1994 PP-07222 EMENT VOL-01739-01 PP-00008). 
não se mostra apto a proteger as posições jurídicas contra eventuais mudanças dos institutos jurídicos ou dos próprios estatutos jurídicos previamente fixados". 8

Segundo a tese do STF, portanto, contra a Constituição não se aplica o princípio da segurança jurídica; porém, como lembra Romeu Felipe Bacellar Filho, quando a Constituição deseja, as ressalvas são incluídas de forma expressa em seu texto originário. ${ }^{9}$ Nesse sentido, o referido autor cita o exemplo concreto disposto no art. 17 do ADCT em que o texto constitucional expressamente impede a utilização do direito adquirido. Segundo o aludido dispositivo, in verbis:

os vencimentos, a remuneração, as vantagens e os adicionais, bem como os proventos de aposentadoria que estejam sendo percebidos em desacordo com a Constituição serão imediatamente reduzidos aos limites dela decorrentes, não se admitindo, neste caso, invocação de direito adquirido ou percepção de excesso a qualquer título.

Para Romeu Felipe Bacellar Filho, o poder reformador da Constituição, por óbvio, não pode ser tido como absoluto: "é imperioso contermos os impulsos reformadores e, com o devido respeito, defender que não é razoável, diante de nossa história, aceitar um poder de reforma absoluto". ${ }^{10}$ Com efeito, deve-se ter em vista que o próprio texto constitucional impõe limites ao poder reformador ao estabelecer, por exemplo, as cláusulas pétreas e as circunstâncias específicas em que se deve dar a possibilidade de reformar a Constituição por meio de emendas. Nesse sentido, Luís Roberto Barroso salienta que o processo de reforma ao texto constitucional deve preservar sua força normativa e assegurar a identidade e a continuidade da Constituição, destacando que os limites impostos costumam ser classificados pela doutrina em temporais, circunstanciais, formais e materiais. ${ }^{11}$

Nesse passo, Bacellar Filho repisa que as normas da Constituição Federal, quando não dispõem em sentido oposto, possuem eficácia imediata, destacando que as normas constitucionais podem, inclusive, retroceder

$8 \quad$ Ibid., p. 369.

9 Romeu Felipe Bacellar Filho, A estabilidade do ato administrativo criador de direitos à luz dos princípios da moralidade, da segurança jurídica e da boa-fé, op. cit., passim.

10 Ibid, passim.

11 BARROSO, Luís Roberto. Curso de direito constitucional contemporâneo. 3. ed. São Paulo: Saraiva, 2011. p. 169-171. 
ao passado, alcançando fatos sob a égide do texto constitucional anterior. Entretanto, como se tem por evidente, o autor aduz que essa alternativa depende de expressa ressalva. ${ }^{12}$

$\mathrm{O}$ impasse que se coloca, na verdade, diz respeito à possibilidade de um eventual desrespeito aos institutos do ato jurídico perfeito e do direito adquirido - ambos uma mera decorrência da ideia geral de segurança jurídica. A legislação infraconstitucional continua válida tão somente se não ocorre confronto com a Constituição anterior. Trata-se do denominado princípio da recepção. Para André Ramos Tavares, o problema situa-se no plano da existência das normas: ocorre uma avaliação das normas anteriores de acordo com os requisitos de validade do novo texto constitucional. $\mathrm{Ou}$ seja, se a legislação infraconstitucional anterior estiver desconforme ao novel texto constitucional, tal legislação é reputada como inexistente, vale dizer, como não normas. ${ }^{13}$ Prevalece, assim, a Constituição atual, tida como norma hierárquica superior do ordenamento jurídico. Destaca-se, assim, o princípio da supremacia constitucional, que para Lenio Luiz Streck é considerado princípio instrumental da interpretação constitucional. ${ }^{14}$ Em razão disso, por conseguinte, fala-se que a eficácia da Constituição é imediata, salvo disposição expressa em contrário constante da própria Constituição. ${ }^{15}$

Romeu Felipe Bacellar Filho ressalta, porém, que tais noções não devem levar à confusão de que a garantia ao direito adquirido e o princípio da irretroatividade da lei dizem respeito à mesma coisa. Para o autor, portanto, demonstra-se equivocado confundir direitos adquiridos - que, em verdade, não se relacionam diretamente e estritamente com o passado, mas sim a efeitos presentes de fatos passados - com a questão da irretroatividade da legislação, que diz respeito à alteração no passado de efeitos já consumados. Dessa forma, tem-se que as duas questões lidam com problemas nitidamente diferentes que, portanto, devem merecer soluções técnicas distintas. ${ }^{16}$

12 Romeu Felipe Bacellar Filho, A estabilidade do ato administrativo criador de direitos à luz dos princípios da moralidade, da segurança jurídica e da boa-fé, op. cit., passim.

13 TAVARES, André Ramos. Curso de direito constitucional. 6. ed. atual. São Paulo: Saraiva, 2008. p. 176.

14 STRECK, Lenio Luiz. Hermenêutica e princípios da interpretação constitucional. In: J. J. Gomes Canotilho, Gilmar Ferreira Mendes, Ingo Wolfgang Sarlet e Lenio Luiz Streck, Comentários à Constituição do Brasil, op. cit., p. 92.

15 Romeu Felipe Bacellar Filho, A estabilidade do ato administrativo criador de direitos à luz dos princípios da moralidade, da segurança jurídica e da boa-fé, op. cit., passim.

16 Ibid., passim. 
Nesse passo, é de bom grado destacar um importante detalhe: a relevante distinção da situação dos aposentados e pensionistas que: i) aposentaram-se e cumpriram os requisitos da aposentadoria antes do advento da Emenda Constitucional no 41/2003; ii) os que se aposentaram após a edição da Emenda, no entanto, cumpriram os requisitos ainda antes do advento da alteração constitucional (e permaneceram em exercício com abono de permanência, por exemplo); e, finalmente iii) aqueles que se aposentaram e cumpriram os requisitos somente após o advento da emenda. Em relação aos primeiros, que se aposentaram e cumpriram os requisitos antes da edição da emenda, trata-se do indiscutível cenário clássico de um ato jurídico perfeito. A segunda situação - isto é, em relação àqueles servidores que cumpriram os requisitos para a aposentação antes da emenda, contudo aposentaram-se somente após o seu advento - deflagra um cenário consolidado de direito adquirido ao regime anterior. Por outro lado, em relação à última situação, daqueles que se aposentaram após a emenda e também cumpriram os requisitos somente posteriormente, tem-se que tais aposentados possuem apenas expectativa de direito. Assim, com relação aos dois primeiros cenários apresentados, indiscutível que esses indivíduos possuem o direito a não instituição da contribuição previdenciária, tendo em vista as garantias do ato jurídico perfeito e do direito adquirido. $\mathrm{O}$ mesmo não ocorre com os últimos, vale dizer, daqueles que se aposentaram após a edição da emenda e cumpriram os requisitos após o seu advento. Com relação a esses servidores, porém, os outros aspectos da inconstitucionalidade da cobrança previdenciária continuam valendo.

Nesses termos, portanto, defende-se aqui a tese de que há sim direito adquirido em face de emendas constitucionais e, do mesmo modo, o ato jurídico perfeito também deve ser respeitado diante de tais espécies normativas. Cabe repisar que as emendas à Constituição, inclusive, consistem em normas-objeto para o controle de constitucionalidade, sendo assente a possibilidade de se falar em "emendas constitucionais inconstitucionais". ${ }^{17}$ Nesse sentido, Clèmerson Merlin Clève salienta que é pacífico que as emendas

17 SARLET, Ingo Wolfgang; BRANDÃO, Rodrigo. Comentários ao artigo 60. In: J. J. Gomes Canotilho, Gilmar Ferreira Mendes, Ingo Wolfgang Sarlet e Lenio Luiz Streck, Comentários à Constituição do Brasil, op. cit., p. 1131. Para os referidos autores, afigura-se cabível o controle de constitucionalidade de emendas constitucionais mediante o controle abstrato, mas também por meio de controle incidental de constitucionalidade, com a devida ressalva de que em tais casos a análise da inconstitucionalidade da emenda consiste tão somente em questão prejudicial ao exame do mérito da causa. 
constitucionais se sujeitam à fiscalização abstrata de constitucionalidade, tendo como parâmetro as cláusulas pétreas. ${ }^{18} \mathrm{E}$ o princípio da segurança jurídica, em suas três vertentes (coisa julgada, ato jurídico perfeito e direito adquirido), é cláusula pétrea.

É verdade, todavia, que as emendas constitucionais possuem hierarquia superior à lei (em sentido formal); por outro lado, como ensinam Carlos Ayres Britto e Valmir Pontes Filho, não é em razão disto que tais espécies normativas estão liberadas da vedação constitucional da imposição de prejuízo ao direito adquirido (ou mesmo já consolidado) pelo respectivo titular. Segundo os referidos autores, se as emendas não foram incluídas na disposição literal do inciso XXXVI do art. 5ำ, isso se deu tão somente em virtude de que o direito ali disposto é exclusivamente o concedido por lei, isto é, não o concedido pela Constituição (em sua concepção originária). Os direitos subjetivos "uma vez adquiridos, seja qual for a respectiva natureza (direito individual, social, político, funcional etc.) não mais se expõem a lesão por conduto de reforma constitucional. A normatividade das emendas, no caso, já nasce etiquetada com o signo do 'doravante', e jamais com o timbre do 'desde sempre $"$ "'. ${ }^{19}$ No mesmo sentido, Regina Maria Macedo Nery Ferrari ensina que "é inconstitucional não só a revisão que venha a suprimir uma ou algumas das vedações ou limites materiais, como aquela que atente contra a essência do direito protegido". ${ }^{20} \mathrm{Ou}$ seja, a autora se refere tanto à norma oriunda de reforma constitucional que pretenda abolir um dos direitos e garantias individuais do cidadão assegurados pelo texto originário da Constituição, assim como àquela que venha ofender o princípio da irretroatividade da lei. ${ }^{21}$

Desse modo, à luz do que preceitua o art. 5ํㅡㄹ inciso XXXVI, da Constituição Federal, deve-se interpretar o termo "lei" ali disposto em um sentido amplo - à luz do que defendem autores como Egon Bockmann Moreira,

18 CLÈVE, Clèmerson Merlin. Temas de direito constitucional. 2. ed. Belo Horizonte: Fórum, 2014. p. 403.

19 BRITTO, Carlos Ayres; PONTES FILHO, Valmir. Direito adquirido contra as emendas constitucionais. In: MELLO, Celso Bandeira de (Coord.). Estudos em homenagem a Geraldo Ataliba: direito administrativo e constitucional. São Paulo: Malheiros, 1997. p. 156-157. Segundo os aludidos autores: "em suma, quer se trate de direito que se adquire em sede legal, quer se trate daquele que se obtém por virtude de norma constitucional, tudo é matéria tabu para as leis e as emendas à Constituição, indistintamente. Um e outro direito subjetivo são alcançados pelo princípio constitucional da segurança jurídica e, nessa medida, garantidos pela petrealidade de que trata o inciso IV do $\S 4^{\circ}$ do art. 60 da Carta de Outubro".

20 FERRARI, Regina Maria Macedo Nery. Direito constitucional. São Paulo: Revista dos Tribunais, 2011. p. 175-176.

21 Ibid., p. 175-176. 
no âmbito do direito administrativo,- 22 isto é, deve-se entender o termo como lei em sentido material, abrangendo-se, portanto, também as emendas constitucionais. Vale dizer, tais espécies normativas também estão submetidas e devem sim respeitar o direito adquirido e o ato jurídico perfeito. ${ }^{23} \mathrm{Em}$ conclusão, merece revisão a atual interpretação, conjuntural e não unânime, do Supremo Tribunal Federal.

\subsection{A aplicação do princípio da confiança, da boa-fé dos servidores inativos e da teoria da perda de uma chance}

Como destacado supra, no ano de 2004 o STF debruçou-se sobre o tema da contribuição previdenciária dos servidores inativos quando declarou a constitucionalidade da cobrança por meio do julgamento da ADIn no 3.105. Em que pese tenha tido conhecimento imediato da declaração de constitucionalidade da cobrança da contribuição previdenciária, alguns entes políticos, como é o caso do estado do Paraná, ao longo de mais de uma década, não implementaram qualquer contribuição em nível estadual. ${ }^{24}$ Nesses casos,

22 Para Egon Bockmann Moreira, o princípio da legalidade abandonou a sua compreensão fechada e positivista, destacando o autor que atualmente a legalidade não retrata mais a concepção de universo de normas fechadas. Para Egon Moreira, portanto o princípio da legalidade exige a compreensão do todo do ordenamento jurídico. Segundo o aludido autor, a expressão "a lei e o Direito" surgiu no direito positivo brasileiro a partir da edição da Lei n 9.784/1999, que regula o processo administrativo no âmbito da administração pública federal. "Pode-se tomar este marco como o instante em que se reconheceu legislativamente o novo tônus que o princípio da legalidade haveria de assumir frente ao Direito Administrativo brasileiro. A partir desse momento, a Administração Pública deve obediência não só ao texto normativo, mas sim à norma construída a partir do texto" (MOREIRA, Egon Bockmann. O princípio da legalidade, a lei e o direito. In: MARRARA, Thiago (Org.). Princípios de direito administrativo: legalidade, segurança jurídica, impessoalidade, publicidade, motivação, eficiência, moralidade, razoabilidade, interesse público. São Paulo: Atlas, 2012. p. 57-58).

23 Segundo Romeu Felipe Bacellar Filho: "o ato administrativo garantidor de direitos encontrase blindado contra a ação da lei nova, seja lei em sentido formal, seja emenda constitucional. Tal conclusão advém da necessária compreensão de que o princípio da segurança das relações jurídicas deve presidir toda a atuação do Poder Público, servindo, através dos institutos que o consagram - ato jurídico perfeito, direito adquirido e coisa julgada - como escudo protetor do cidadão frente à superveniência de lei ou emenda constitucional que frustre suas expectativas diante de situações jurídicas já consolidadas" (Romeu Felipe Bacellar Filho, A estabilidade do ato administrativo criador de direitos à luz dos princípios da moralidade, da segurança jurídica e da boa-fé, op. cit., passim).

24 Nesse contexto, assim permaneceu o sistema previdenciário estadual ao longo de todo esse período, até a edição da Lei no 18.370/2014. Com efeito, durante certo tempo o Ministério da Previdência Social se recusou a emitir o Certificado de Regularidade Previdenciária para o estado do Paraná. Sem o certificado, a União Federal bloqueava a transferência de uma diversidade de recursos ao estado. Assim, o estado do Paraná ingressou com ação no STF para 
produziu-se uma situação de segurança aos aposentados no âmbito de vigência do regime não contributivo. Com efeito, em que pese a declaração de constitucionalidade do STF da contribuição em questão, o ente político local decidiu que ela não seria aplicada, em razão da autonomia decorrente do pacto federativo.

A situação descrita insere-se no que é tradicionalmente denominado de princípio da confiança. Como ensina José J. Gomes Canotilho, “o homem precisa de segurança para conduzir, planificar e conformar autônoma e responsavelmente a sua vida. Por isso, desde cedo se consideravam os princípios da segurança jurídica e da proteção da confiança como elementos constitutivos do Estado de direito". ${ }^{25}$ Nesse sentido, Juarez Freitas aduz que o princípio da confiança legítima dos destinatários da administração pública (e vice-versa) deve ocupar um lugar de destaque no controle das relações da administração pautado no primado dos princípios. Para o autor, "é essencial elevar a confiabilidade das instituições públicas, razão pela qual se impõe o controle mais qualitativo das políticas públicas, no sentido de promover forte redução da insegurança jurídica" ${ }^{26}$

Jaime Rodríguez-Arana Muñoz, ao falar da existência de um direito fundamental à boa administração pública, destaca o princípio da confiança legítima como um de seus corolários. Segundo o autor, o princípio em questão preceitua que a atuação do poder público não pode afrontar as expectativas que razoavelmente tenham gerado no passado. ${ }^{27}$ Dessa forma, os servidores públicos, confiando no agir estabelecido pelo Estado, elaboraram planos de

questionar a obrigatoriedade de realizar a cobrança previdenciária dos servidores inativos paranaenses, obtendo tutela antecipatória que garantiu liminarmente que o estado não poderia sofrer qualquer espécie de sanção pela não cobrança previdenciária.

25 CANOTILHO, José Joaquim Gomes. Direito constitucional e teoria da Constituição. Coimbra: Almedina, 2000. p. 256. Nesse contexto, para Leonardo Coelho Ribeiro e Rafael Véras de Freitas, a administração possui um dever de coerência administrativa, destacando que a imprevisibilidade e a insegurança jurídica impõem custos transacionais desnecessários ao desenvolvimento nacional. (RIBEIRO, Leonardo Coelho; FREITAS, Rafael Véras de. Manutenção do ambiente negocial entre o público e o privado e desenvolvimento nacional: o impacto das modulações regulatórias nos contratos da administração e o dever de coerência administrativa. In. CÔRREA, André Rodrigues; PINTO JÚNIOR, Mario Engler (Org.). Cumprimento de contratos e razão de Estado. São Paulo: Saraiva, 2013. p. 410-412 e 423.

26 FREITAS, Juarez. O controle dos atos administrativos e os princípios fundamentais. São Paulo: Malheiros, 2013. p. 83-84.

27 RODRÍGUEZ-ARANA MUÑOZ, Jaime. Direito fundamental à boa administração pública. Belo Horizonte: Fórum, 2012. p. 171. Para Jaime Rodríguez-Arana Muñoz: “hoje, no século XXI, o cidadão, como já observamos, já não é um sujeito inerte à mercê dos caprichos do poder. Hoje o cidadão participa na determinação do interesse geral que não é mais definido unilateralmente pela Administração Pública" (p. 158-159). 
acordo com uma posição firmada preteritamente, consolidada em âmbito estadual, apesar da decisão firmada pelo STF. Ou seja, esses servidores optaram deliberadamente pela aposentaria, tendo em vista o comportamento expresso do ente federativo local com relação aos seus aposentados e pensionistas. Nesse particular, Maria Sylvia Zanella di Pietro chama atenção para este ponto: se o Poder Público adotou determinada interpretação, não pode posteriormente, por respeito à boa-fé, anular os atos anteriores, sob o argumento de que eles foram praticados pautados em uma interpretação equivocada. ${ }^{28}$

Deve-se ter em vista, ainda, que, ao confiar no agir consolidado da administração pública, tal confiança gerou efeitos concretos à vida dos cidadãos. Como exemplo, tome-se o caso daqueles indivíduos que decidiram aposentarse renunciando à possibilidade de continuar em exercício mediante o pagamento de abono de permanência: caso soubessem que haveria posterior mudança de orientação político-administrativa por parte do poder público, possivelmente teriam tomado uma decisão diferente, tendo em vista a significativa mudança financeira que teriam em suas vidas. Ou ainda, o caso daqueles servidores que contrataram um empréstimo consignado. De acordo com o art. $2^{\circ}$, $\S 2^{\circ}$, inciso I, da Lei $\mathrm{n}^{\mathrm{o}}$ 10.820/2003, existe um limite de $30 \%$ da remuneração disponível para a consignação. Considerando, assim, que os servidores não podem ter descontados mais de 30\% do valor do benefício da aposentadoria a título de empréstimo consignado, é indiscutível que a mudança de um entendimento consolidado da administração, mediante a instituição da contribuição previdenciária, trouxe prejuízos concretos em suas vidas deixando-os em situação remuneratória inferior do legalmente aceito pelo ordenamento brasileiro. ${ }^{29}$

Nesse aspecto, tendo em vista a efetiva incidência do princípio da confiança, cumpre mencionar a aplicação da teoria da perda de uma chance ao caso. No sentido jurídico, a perda de uma chance é a probabilidade real de alguém obter um lucro ou evitar um prejuízo; vale dizer, o autor do ato (no caso, o poder público), por meio da sua conduta, faz com que a vítima perca a oportunidade de conseguir uma situação futura melhor. ${ }^{30}$ Essa teoria

28 DI PIETRO, Maria Sylvia Zanella. Direito administrativo. 17. ed. São Paulo: Atlas, 2004. p. 85.

29 Nesse sentido, o Superior Tribunal de Justiça decidiu que a soma mensal das prestações referentes ao empréstimo consignado não pode ultrapassar 30\% dos vencimentos (REsp 1186965/RS, rel. ministro MASSAMI UYEDA, TERCEIRA TURMA, julgado em 7/12/2010, DJe 3/2/2011).

30 CAVALIERI FILHO, Sérgio. Programa de responsabilidade civil. 8. ed. São Paulo: Atlas, 2008. p. 75. 
é aplicada, inclusive, pelo Superior Tribunal de Justiça que exige, entretanto, que esse dano configure-se como real, atual e certo, dentro de um juízo de efetiva probabilidade, e não mera possibilidade (REsp 1.104.665-RS, rel. min. Massami Uyeda, julgado em 9/6/2009). No caso dos servidores inativos, vê-se que o dano real é cristalinamente definido e efetivo, haja vista que os servidores não puderam tomar a decisão de permanecer em exercício, recebendo o abono de permanência, porquanto estariam automaticamente isentos da contribuição previdenciária ao se aposentarem, em virtude da posição firmada no estado do Paraná.

Todas estas situações decorrem, portanto, da plena incidência do princípio da confiança entre os cidadãos e o poder público. Com efeito, indiscutível que alterar uma posição do poder público consolidada por vários anos ofende frontalmente o princípio em questão. Ademais, em que pese a justa expectativa criada pelo poder público (e a plena incidência do princípio da confiança), cumpre repisar, conforme já dito no tópico anterior, que se os indivíduos se aposentaram sob um regime que não exigia contribuição para a aposentadoria e, em sendo os atos jurídicos que consumaram as suas respectivas inativações absolutamente perfeitos, não podem sofrer incidência de legislação posterior. ${ }^{31}$ A aposentadoria, uma vez regularmente concedida aos cidadãos, não pode ser unilateralmente alterada pelo Estado. ${ }^{32}$

Nessa senda, a conclusão é que o ato jurídico perfeito ao tempo da aposentação deve ser indiscutivelmente respeitado. A cobrança da contribuição previdenciária em face dos servidores aposentados agride de modo inconciliável a respectiva boa-fé de cada um; isto é, o respeito pela palavra empenhada, pela certeza de um direito alcançado, pela expectativa do correto cumprimento gerada na contraparte, pela confiabilidade da conduta, pela justa esperança de um comportamento leal. Portanto, os cidadãos, motivados

31 “Na aplicação do Direito Previdenciário raramente a lei retroage, como acontece em outros ramos jurídicos, mas é comum ditame novo alterar a avaliação dos elementos pertencentes ao passado, para melhor. Na interpretação e integração, isto é, nos casos de obscuridade e fissura da norma jurídica vigente à época dos acontecimentos, é cabível a argumentação relativa à posterior mais benéfica. Mas, a regra é a irretroatividade da norma, cabendo considerar o valor dos fatos e da lei vigente à época." (MARTINEZ, Wladimir Novaes. Curso de direito previdenciário. Tomo I - Noções de direito previdenciário. São Paulo: LTR, 1997. p. 120).

32 "A aposentadoria de servidor público, uma vez decretada, assume o caráter de 'actus perfectus', ficando subordinada à lei do tempo de sua decretação, com todas as vantagens que lhe foram atribuídas. Não pode ser alterada ou modificada. Mesmo com o advento de norma posterior, se sujeita por inteiro à lei antiga." (BITTENCOURT, Mario Diney Corrêa. Aposentadoria de servidor público - ato jurídico perfeito - direito adquirido - irretroatividade das normas. Revista dos Institutos dos Advogados do Paraná, n. 26, p. 225, 1996). 
pela convicção da boa-fé, não merecem ser vilipendiados em seus direitos pela desleal ação da administração pública que, desacreditando o princípio da segurança das relações jurídicas, pretende impor-lhes uma impertinente e inconstitucional obrigação.

\subsection{A vedação constitucional ao confisco e o caráter alimentar das prestações previdenciárias}

Mesmo após a edição da Emenda Constitucional no 41/2003, o direito de abstenção contributiva dos aposentados do regime geral permaneceu expressamente consagrado no texto constitucional, conforme o inciso II, do art. 195, verbis: "não incidindo contribuição social sobre aposentadoria e pensão do regime geral de previdência social de que trata o art. 201". Há um sentido para tal proibição.

Em verdade, cobrar após a aposentação significa impor um verdadeiro imposto sobre os proventos dos servidores inativos - uma redução salarial travestida de "contribuição". Mais do que isso: significa, na realidade, a configuração de confisco, vedado expressamente pela Constituição Federal. O confisco consiste na "absorção total ou substancial da propriedade privada, pelo Poder Público, sem a correspondente indenização" ${ }^{33}$ E, como é amplamente cediço, a impossibilidade de utilização de tributo com efeito de confisco é consagrada no art. 150, inciso IV, da Constituição Federal.

Para Regina Helena Costa, a vedação da utilização do tributo com efeito de confisco deriva do princípio da capacidade contributiva; é efeito deste, pois os tributos devem ser graduados segundo a capacidade contributiva do contribuinte. ${ }^{34}$ A autora afirma que o tributo será confiscatório, portanto, quando exceder capacidade contributiva relativa. ${ }^{35}$ Heleno Torres, por seu

33 COSTA, Regina Helena. Princípio da capacidade contributiva. 4. ed. atual. São Paulo: Malheiros, 2012. p. 83.

34 COSTA, Regina Helena. Curso de direito tributário: Constituição e Código Tributário Nacional. 4. ed. São Paulo: Saraiva, 2014. p. 95. Nesse sentido, Roque Antonio Carraza aduz que: “ Estamos convencidos de que o princípio da não confiscatoriedade, contido no art. 150, IV, da CF (pelo qual é vedado 'utilizar tributo com efeito de confisco'), deriva do princípio da capacidade contributiva. Realmente, as leis que criam impostos, ao levarem em conta a capacidade econômica dos contribuintes, não podem compeli-los a colaborar com os gastos públicos além de suas possibilidades" (CARRAZA, Roque Antonio. Curso de direito constitucional tributário. 10. ed. São Paulo: Malheiros, 1995. p. 70).

35 Ibid., p. 96. 
turno, ensina que o princípio da proibição do excesso consiste em corolário do princípio da segurança jurídica como forma de expressão de justiça quanto ao exercício dos direitos de propriedade e de liberdade. O autor destaca que "o confisco é sempre algo que supera os limites do suportável e do razoável". ${ }^{36}$ Dessa forma, destaca que um dos objetivos do princípio em questão consiste na proibição de excessivas exigências tributárias por parte do Estado, mediante indevida apropriação do patrimônio ou rendimentos dos contribuintes, de modo a garantir o equilíbrio da carga tributária. ${ }^{37}$ Conforme pondera Daniel Wunder Hachem: "as restrições a direitos fundamentais operadas em nome do interesse da coletividade deverão ser realizadas em conformidade com o ordenamento jurídico, notadamente com os princípios da proporcionalidade e da razoabilidade" ${ }^{38}$

Nesse particular, é possível afirmar a total irrazoabilidade da cobrança quando lembrado que o benefício de aposentadoria possui uma inconteste natureza alimentar, que deveria ser imune à constrição. Nesse sentido, Wladimir Novaes Martinez destaca: “atribui-se natureza alimentar às prestações previdenciárias; elas são a contribuição dos ingressos obtidos antes do deferimento dos benefícios (...)" ${ }^{39}$ Em possuindo natureza alimentar, a preocupação do legislador com os proventos de aposentadoria deveria ser redobrada, mormente em relação à tributação incidente. No caso da cobrança da contribuição previdenciária sobre os inativos, o que se nota é a desconsideração da capacidade contributiva dos servidores inativos e pensionistas (art. 145, §1ํㅡㄹ da Constituição), que dependem do Erário para sua sobrevivência, caracterizando, assim, um cenário de confisco.

Regina Helena Costa lembra, contudo, que nem sempre é fácil verificar até que ponto um tributo não é confiscatório e a partir de quando ele passa a sê-lo. A resposta, segundo a autora, deve-se apoiar na equidade e na razoabilidade. ${ }^{40}$ Assim, embora seja subjetiva a delimitação do ponto em que um tributo/contribuição passa a ser confiscatório, no caso da cobrança sobre os inativos, tal cenário mostra-se indiscutível, porquanto está se cobrando

36 TORRES, Heleno. Comentários ao artigo 150, inciso IV. In: J. J. Gomes Canotilho, Gilmar Ferreira Mendes, Ingo Wolfgang Sarlet e Lenio Luiz Streck, Comentários à Constituição do Brasil, op. cit., p. 1641.

37 Ibid., p. 1642.

38 HACHEM, Daniel Wunder. Princípio constitucional da supremacia do interesse público. Belo Horizonte: Fórum, 2011. p. 336.

39 Wladimir Novaes Martinez, Curso de direito previdenciário, op. cit., p. 299.

40 Regina Helena Costa, Curso de Direito Tributário, op. cit., p. 96. 
uma contribuição sem a devida contraprestação, conforme será demonstrado no tópico subsequente.

\subsection{A impossibilidade material da imposição de descontos previdenciários aos servidores inativos: cenário de tributação sem causa e a ausência de contraprestação estatal}

Insta destacar que a cobrança da contribuição previdenciária sobre os servidores inativos não passa de um modo de o Estado eximir-se de pagar o que deve, porquanto a contribuição legal é baseada no trabalho e não em proventos (estes, já considerados, por definição, uma contraprestação). ${ }^{41}$ A cobrança de pseudoprevidência sobre os proventos dos servidores inativos constitui-se em uma manifesta inconstitucionalidade ao violar frontalmente os princípios da contributividade, da retributividade direta e o princípio de que não haverá tributação sem causa. ${ }^{42}$ Isto é, uma lei que realize a previsão da cobrança em comento não institui qualquer benefício aos inativos que possa ser vista como uma retribuição pela contribuição; ao contrário, a exigência decorre apenas, e tão somente, do déficit financeiro gerado pela ineficiência do governo do Estado na administração do sistema previdenciário. ${ }^{43}$ Trata-se

41 Como ensina Wladimir Novaes Martinez: “uma vez fixado o valor final do benefício, isto é, a renda mensal, descabe qualquer tipo de desconto de caráter previdenciário. Salvo se o sistema admitir a hipótese de, durante a vida ativa do segurado, ele contribuir para si e (sob alíquota menor) para as prestações dos dependentes e, aposentando-se, cotizar exclusivamente para a pensão. Fora dessa circunstância não pode haver desconto previdenciário no valor do benefício. Ele desnatura o sentido da contribuição, pois ela tem direção, o benefício, e este já se realizou" (Wladimir Novaes Martinez, Curso de direito previdenciário, op. cit., p. 314).

42 Por outro lado, autores como Daniel Machado da Rocha, seguindo a linha argumentativa proposta pelo STF no julgamento da ADIn no 3.105 (calcada no princípio da solidariedade), defendem que a cobrança da contribuição previdenciária sobre os inativos serviu justamente para fortalecer ainda mais o equilíbrio financeiro atuarial. (ROCHA, Daniel Machado da. Comentários ao artigo 40. In: J. J. Gomes Canotilho, Gilmar Ferreira Mendes, Ingo Wolfgang Sarlet e Lenio Luiz Streck, Comentários à Constituição do Brasil, op. cit., p. 978).

43 Os argumentos a favor da contribuição em questão, como pode ser notado, são meramente pragmáticos. Em manifestação na Assembleia Legislativa do Estado (Alep), o secretário estadual da Fazenda reconheceu que o governo do estado do Paraná cometeu erros que geraram um déficit financeiro. Segundo matéria do site de notícias G1: “O secretário da Fazenda do Paraná, Mauro Ricardo Costa, apresentou nesta quarta-feira (4) os resultados financeiros do estado no terceiro quadrimestre de 2014. Em audiência pública na Assembleia Legislativa (Alep), ele admitiu erros cometidos no primeiro mandato do governador Beto Richa (PSDB), como superestimar os orçamentos elaborados, e alterações feitas na previdência dos servidores". 
de um fundamento pragmático disfarçado (falta dinheiro, então se reduz materialmente a despesa por meio do formal aumento da arrecadação).

Denota-se, assim, que a instituição da contribuição previdenciária sobre os servidores inativos veio desacompanhada de qualquer contraprestação, decorrendo tão somente de uma necessidade financeira da administração pública. No fundo, cobrar contribuição dos aposentados significa simplesmente reduzir seus proventos. Como pode ser verificado, a exigência ofende de forma frontal o disposto no art. 195, $5^{\circ}$, da Constituição Federal, quando prescreve que "nenhum benefício ou serviço da seguridade social poderá ser criado, majorado ou estendido sem a correspondente fonte de custeio total". Nesse particular, o dispositivo em comento decorre, a contrario sensu, da garantia de que a criação de uma nova exação previdenciária só se justifica se ocorrer o estabelecimento também de novo benefício em prol do servidor inativo. ${ }^{44}$

Contudo, no caso da cobrança dos servidores inativos e pensionistas, o que se vislumbra é que à nova contribuição não corresponderá nenhum novo benefício. E se não há contraprestação, não pode o Estado exigir a contribuição previdenciária, porquanto o próprio texto do art. 149, da Constituição, impõe como requisito para o desconto a existência de um benefício, em contrapartida, ao prescrever que: “Os Estados, o Distrito Federal e os Municípios poderão instituir contribuição cobrada de seus servidores, para o custeio, em benefício destes, de sistemas de previdência e assistência social". Ora, obviamente que a contribuição dos inativos não será em seu benefício.

Repise-se que no julgamento da ADIn no 2.010 o STF entendeu que, assim como não se admitia o aumento de benefício sem a respectiva fonte de custeio, também não poderia admitir o incremento da fonte de custeio sem o respectivo incremento do benefício. Por outro lado, no julgamento da ADIn no 3.105, como visto, o Pretório Excelso alterou esse entendimento ao aduzir que o princípio da retributividade direta garante tão somente o não aumento

44 Rememore-se que, no julgamento da ADIn no 2.010, o STF, ao entender ser inconstitucional a instituição da contribuição previdenciária sobre os inativos, posicionou-se no sentido de que o princípio do equilíbrio financeiro-atuarial - que garantiria a solvabilidade do regime previdenciário - voltava-se tão somente para os servidores ativos, isto é, para aqueles que, a rigor, ocupavam cargo efetivo. Daniel Machado da Rocha lembra que "na mesma decisão, o relator, Ministro Celso de Mello, asseverou um outro fundamento não menos relevante: a transgressão, por parte da Lei n. 9.783/99, do princípio do equilíbrio financeiro e atuarial, uma vez que, não havendo nenhum benefício para os servidores inativos contribuírem para o regime dos servidores públicos, inexistira causa para a instituição da contribuição". (Daniel Machado da Rocha, Comentários ao artigo 40, op. cit., p. 979). Porém, como é cediço, tal entendimento foi alterado com o julgamento da ADIn no 3.105. 
do benefício sem a correspondente fonte de custeio. Nesse vértice, cumpre assentar que o princípio da retributividade direta vem tendo seu conteúdo esvaziado pelas diversas iniciativas normativas de aumento das fontes de custeio da seguridade social sem o respectivo aumento dos benefícios dos servidores.

Segundo Damares Medina, a contribuição previdenciária sobre os inativos não constitui um caso isolado de quebra do princípio em questão. O poder público vem constituindo uma prática que tende a se tornar regra. $\mathrm{O}$ autor lembra que esse aspecto foi, inclusive, destacado pelo então ministro do STF Carlos Ayres Britto, no julgamento do Recurso Extraordinário no 415.545, que versa sobre as correções das pensões por morte dos segurados do INSS, em que traçou um quadro de todas as hipóteses de aumento das fontes de custeio da seguridade social, sem o correspondente aumento dos benefícios. ${ }^{45}$ Nesse cenário, o então procurador-geral da República, Antonio Fernando Barros e Silva de Souza, quando do julgamento da ADIn no 3.105, elaborou a seguinte indagação: “qual o benefício futuro a que terá direito o aposentado ou pensionista que recolher a contribuição nos moldes estatuídos pelo art. 4으, da EC no 41/03? Não há resposta para a pergunta, o que corrobora o entendimento de que o legislador reformador criou tributo sem causa" ${ }^{46}$

Destarte, admitir o entendimento dado pelo STF (no julgamento da ADIn $\mathrm{n}^{\mathrm{o}}$ 1.105) ao artigo 195, §5ํㅡㄹ é incorrer em um manifesto equívoco, tendo em vista a configuração de um cenário de tributação sem causa, como, inclusive, adverte José Afonso da Silva. ${ }^{47}$ É como se as fontes de custeio pudessem

45 MEDINA, Damares. O Supremo Tribunal Federal e a contribuição previdenciária dos servidores inativos. Jusbrasil. Disponível em: <http://jus.com.br/artigos/11797/o-supremotribunal-federal-e-a-contribuicao-previdenciaria-dos-servidores-inativos $>$. Acesso em: 19 abr. 2015. Segundo conclui o aludido autor, a garantia constitucional da fonte de custeio, como desdobramento do princípio da retributividade, teve seu significado modificado pela jurisprudência do STF. Para Damares Medina, a Emenda Constitucional no 41/2003 e o julgamento da ADIn no 3.105 podem ser considerados o início dessa "virada interpretativa".

46 STF - Ação Direta de Inconstitucionalidade 3105 DF, relator: min. ELLEN GRACIE, Data de Julgamento: 18/8/2004, Tribunal Pleno, Data de Publicação: DJ 18-02-2005 PP-00004 EMENT VOL-02180-02 PP-00123 RTJ VOL-00193-01 PP-00137 RDDT n. 140, 2007, p. 202-203. Transcrição às fls. 154 do Acórdão, voto da min. Ellen Gracie. Ainda, veja-se a lição de Misabel Derzi, citada no julgamento da ADIn no 3.105: "se o servidor já goza de aposentadoria, a meta constitucional permitida para a cobrança já foi alcançada, inexiste a despesa a ser custeada do ponto de vista do aposentado, pois os servidores públicos em atividade a financiam. Falta então o fundamento constitucional necessário e impostergável, que funda o exercício da competência da União" (DERZI, Misabel. Da instituição de contribuição sobre proventos dos servidores inativos. Enfoque Jurídico, n. 2, p. 13, Suplemento).

47 Segundo José Afonso da Silva: “os servidores, nos termos do art. 40 (da Constituição Federal) contribuem para que venham a perceber proventos de aposentadoria. Quando eles alcançam 
ser majoradas de uma forma indefinida, com o objetivo único de impedir a insolvabilidade do sistema previdenciário, tudo em prol de uma suposta solidariedade universal (argumento este utilizado de forma totalmente equivocada).

\subsection{A vedação constitucional ao bis in idem}

Além da questão relativa à tributação sem causa e da retributividade direta discutida anteriormente, a cobrança da contribuição previdenciária sobre os inativos também não se justifica sob a forma de tributação sobre a renda, tendo em vista que os aposentados e pensionistas já sofrem a incidência do correspondente imposto de renda. A natureza jurídica das contribuições previdenciárias era controversa na doutrina. Alguns afirmavam que era um imposto, outros diziam que era uma taxa, outros ainda afirmavam que nem se tratava propriamente de um tributo. Regina Helena Costa aduz que as contribuições podem revestir a materialidade de imposto ou taxa, porém não se confundem com tais figuras. Categoria, portanto, que ensejou uma grande controvérsia no passado, a referida autora admite que hoje é reconhecida a feição tributária das contribuições, inclusive das previdenciárias. ${ }^{48}$ Lembre-se, ademais disso, que o próprio STF no julgamento da ADIn nº 3.105 deliberou a respeito do caráter da contribuição previdenciária prevista no $\S 1^{\mathrm{0}}$ do artigo 149.

essa prestação, ocorre como que um acerto de contas entre o contribuinte e o Ente público. (...) Vale dizer, a tese do déficit da previdência ou a tese de que os atuais aposentados não contribuíram ou contribuíram pouco para a previdência não são causas legítimas para a imposição a eles de contribuição" (STF - Ação Direta de Inconstitucionalidade 3105 DF, relator: min. ELLEN GRACIE, Data de Julgamento: 18/8/2004, Tribunal Pleno, Data de Publicação: DJ 18-02-2005 PP-00004 EMENT VOL-02180-02 PP-00123 RTJ VOL-00193-01 PP-00137 RDDT n. 140, 2007, p. 202-203. Parecer referido às fls. 147 e 148 do Acórdão).

48 Regina Helena Costa, Curso de direito tributário, op. cit., p. 148-150. A respeito da caracterização das contribuições previdenciárias, Regina Helena Costa aduz que sua instituição está autorizada para que funcione como um instrumento de atuação da União Federal, estando, assim, atrelada ao atendimento de uma das finalidades apontadas pela Constituição da República. (p. 148). Para Roque Antonio Carraza, as contribuições constituem tributos qualificados constitucionalmente pelas suas finalidades. (Roque Antonio Carraza, Curso de direito constitucional tributário, op. cit., p. 598). Por seu turno, Geraldo Ataliba considera as contribuições como tributos vinculados "cuja hipótese de incidência consiste numa atuação estatal direta e mediatamente (mediante uma circunstância intermediária) referida ao obrigado" (ATALIBA, Geraldo. Hipótese de incidência tributária. 5. ed. São Paulo: Malheiro Editores, 1993. p. 150). 
Mas no caso em questão o problema vai muito além da mera caracterização conceitual das contribuições previdenciárias, porquanto, na medida em que os servidores inativos não terão uma contraprestação em face dos descontos efetuados, conforme já destacado, a contribuição perde suas características ontológicas, tornando-se um "imposto disfarçado". A distinção essencial entre contribuição e imposto reside justamente no fato de que, nas contribuições previdenciárias, o caráter sinalagmático da relação jurídica é irrecusável. Assim, retirando tal distinção, tem-se que a contribuição previdenciária se transmuda em um imposto ilícito. E, em assim sendo, jamais poderia incidir sobre os proventos dos aposentados, na medida em que já existe o "imposto de renda e proventos de qualquer natureza", que possui idêntica base de cálculo.

Nesse sentido, José Afonso da Silva salienta que a cobrança dos inativos é inconstitucional, na medida em que a cobrança não tem, em verdade, natureza previdenciária, mas de um simples imposto incidente sobre os proventos da inatividade com caráter de tributação de renda. Assim, segundo o autor, deflagra-se um cenário de dupla tributação, com infringência ao princípio da igualdade. ${ }^{49}$ Vale dizer, ao configurar um cenário de bis in idem sobre os proventos de aposentadoria, ofende-se manifestamente o princípio da isonomia tributária, porquanto um duplo imposto de renda recai tão somente sobre os aposentados e pensionistas.

A nova exigência sobre os proventos dos aposentados mostra-se igualmente inconstitucional por caracterizar verdadeiro bis in idem em relação aos valores normalmente já recolhidos sob esse título à União Federal. Portanto, a instituição da contribuição previdenciária sobre os inativos viola a garantia de que não haverá mais de um imposto sobre o mesmo fato gerador. ${ }^{50}$ Ademais, o Estado-membro não pode criar um imposto distinto daqueles cuja competência lhe é conferida pelo texto constitucional. A competência tributária residual é privativa da União Federal, e mesmo esta não pode instituir imposto com fato gerador ou base de cálculo igual aos discriminados constitucionalmente.

Corroborando essa posição, a ministra Ellen Gracie no julgamento da ADIn nº 3.105 defendeu em seu voto a caracterização do bis in idem, afirmando a ocorrência de tributação dos rendimentos. ${ }^{51}$ No mesmo vértice,

49 SILVA, José Afonso. Curso de direito constitucional positivo. São Paulo: Malheiros, 2013. p. 693.

50 "Art. 154. A União poderá instituir: I - mediante lei complementar, impostos não previstos no artigo anterior, desde que sejam não cumulativos e não tenham fato gerador ou base de cálculo próprios dos discriminados nesta Constituição".

51 Segundo a então ministra Ellen Gracie: “dir-se-á que a tributação não é sobre o aposentado, mas sobre os proventos, e, assim, a causa e fato gerador da contribuição do inativo é a percepção dos 
Sacha Calmon Navarro Coêlho defende a inconstitucionalidade da cobrança, ressaltando que a contribuição previdenciária não pode ser cobrada dos servidores inativos em razão de configurar um verdadeiro imposto sobre a renda dos aposentados..$^{52}$

\subsection{A solidariedade para fins previdenciários e o princípio da proibição do retrocesso social: criação de ônus sobre os vulneráveis é uma cruel inversão da lógica do preceito}

Como já relatado, através do julgamento da ADIn nº 3.105, o STF concluiu pela constitucionalidade da contribuição previdenciária dos servidores inativos. E um dos argumentos centrais dos votos na oportunidade foi um suposto dever de solidariedade de todos para a preservação da previdência social, incluindo os servidores inativos e pensionistas. No julgamento em questão, o STF entendeu que o princípio da solidariedade previdenciária, introduzido então no caput do artigo 40 da Constituição, através da Emenda Constitucional no 41/2003, justificaria a instituição da contribuição previdenciária dos inativos em prol unicamente da solvabilidade do sistema previdenciário (atendendo-se, supostamente, ao equilíbrio financeiro atuarial).

É exatamente o argumento defendido por Daniel Machado da Rocha, para o qual a reforma previdenciária promovida pela Emenda Constitucional em questão fortaleceu ainda mais o princípio do equilíbrio financeiro atuarial. ${ }^{53}$ O conceito de crise utilizado pelo mencionado autor, entretanto, apoia-se unicamente em argumentos de cunho pragmático; ou seja, argumentos que não são jurídicos e que não são éticos. Reserva-se o autor a desconsiderar a análise

proventos. Se é assim, então temos, não uma contribuição previdenciária, mas uma tributação de rendimentos, um bis in idem de caráter discriminatório. Bis in idem porque os proventos de aposentadoria estão sujeitos ao imposto geral sobre a renda e proventos de qualquer natureza, logo outra incidência com igual natureza constituirá uma duplicação ilegítima" (STF - Ação Direta de Inconstitucionalidade 3105 DF, relator: min. ELLEN GRACIE, Data de Julgamento: 18/8/2004, Tribunal Pleno, Data de Publicação: DJ 18-2-2005 PP-00004 EMENT VOL-02180-02 PP-00123 RTJ VOL-00193-01 PP-00137 RDDT n. 140, 2007, p. 202-203. Transcrição às fls. 149 do Acórdão, voto da min. Ellen Gracie).

52 “Todavia, a contribuição in examen não pode ser exigida dos inativos. A contribuição é finalística e retributiva. Seu pagamento após a aposentadoria do funcionário ou sua exigência dos dependentes, após a morte daquele, caracteriza imposto para financiar outrem (caráter distributivo). É imposto sobre a renda. A inconstitucionalidade aproposita-se, claramente" (COÊLHO, Calmon Navarra. Direito tributário contemporâneo. São Paulo: Revista dos Tribunais, 1997. p. 93).

53 Daniel Machado da Rocha, Comentários ao artigo 40, op. cit., p. 978. 
dos fundamentos inerentes à manifesta inconstitucionalidade material da cobrança em tela. Como bem adverte Elival da Silva Ramos, "é injustificável o STF subordinar-se aos fatos, ao invés da Constituição". ${ }^{54}$ Mas é exatamente isso o que ocorreu.

Ao contrário do entendimento do STF, o que o princípio da solidariedade previdenciária estabelece é a cooperação dos vários entes, públicos e privados, para a criação e a manutenção de ações nas áreas de saúde e previdência social. Só isso. Ou seja, a elaboração de um conjunto de ações integradas para o custeio da seguridade social como um todo. Como se tem por evidente, isto não deveria significar o dever de contribuição daqueles que, já tendo contribuído a vida inteira, têm agora o direito a usufruir do sistema previdenciário. Tal entendimento, em verdade, cria um verdadeiro ônus sobre um grupo de pessoas que está em evidente situação de vulnerabilidade. $\mathrm{O}$ Supremo Tribunal Federal inverteu completamente a lógica que informa o preceito da solidariedade.

A situação de vulnerabilidade dos idosos (aposentados e pensionistas) é destacada por autores como Ana Carolina Brochado Teixeira e Gustavo Pereira Leite Ribeiro, para os quais o idoso merece ser tutelado de uma forma diferenciada, por meio de um tratamento específico, a fim de suprir os déficits existentes. ${ }^{55} \mathrm{O}$ cenário de vulnerabilidade dos idosos também é evidenciado

54 RAMOS, Elival da Silva. Ativismo judicial: parâmetros dogmáticos. São Paulo: Saraiva, 2010. p. 245. A respeito do pragmatismo, Richard Posner aduz que o pragmático enfatiza os fatos, é empírico, ou seja, "deseja estar bem informado sobre o funcionamento, as propriedades e os efeitos prováveis de diferentes planos de ação". Nesse particular, Posner salienta que a atitude pragmática é ativista. O pragmático defende que as normas jurídicas devem ser encaradas como instrumentais na consecução dos seus objetivos. Os pragmáticos defendem, nesse particular, uma ampliação das "fronteiras da interpretação", na qual os juízes orientam suas decisões em razão de suas consequências práticas. "Ao abordarem uma questão que tenha sido colocada como de interpretação de uma lei, os pragmatistas perguntarão qual das resoluções possíveis tem as melhores consequências, considerando-se tudo aquilo que é ou deveria ser do interesse dos juristas, incluindo-se a importância de preservar a linguagem como meio de comunicação eficaz e de preservar a separação dos poderes, através do acatamento, em linhas gerais, das decisões do legislativo relativamente ao interesse público". Em resumo, o pragmatismo é uma rejeição da noção de que o direito é fundado em princípios imutáveis e permanentes (POSNER, Richard A. Para além do direito. São Paulo: WMF Martins Fontes, 2009. p. 5, 421-423 e 428). "O pragmatismo abre uma brecha para que, caso a caso, seja preenchido o fundamento da ação, por uma razão interessada, segundo as conveniências dos respectivos autores", destacando que os autores pragmáticos, apesar de estarem além de qualquer cunho totalitário, acabam possibilitando o surgimento de ideais não democráticos (GABARDO, Emerson. Interesse público e subsidiariedade: o Estado e a sociedade civil para além do bem e do mal. Belo Horizonte: Fórum, 2009. p. 195).

55 TEIXEIRA, Ana Carolina Brochado; RIBEIRO, Gustavo Pereira Leite. Procurador para cuidados de saúde do idoso. In: PEREIRA, Tânia da Silva; OLIVEIRA, Guilherme de. Cuidados e vulnerabilidade. Paulo: Atlas, 2009. p. 5. "Nas situações concretas de vulnerabilidade ou 
por Heloisa Helena Barboza, que chama atenção também para a sua lamentável "invisibilidade" na sociedade, situação que acaba por excluir tais indivíduos do sistema produtivo e economicamente ativo. ${ }^{56}$ Destarte, quando a Constituição dispõe que "a seguridade social será financiada por toda a sociedade" em seu art. 195, tal afirmação, de todo óbvio, possui um caráter genérico e admite exceções evidentes, inerentes a qualquer regime público, no qual os trabalhadores sustentam os aposentados. Mais do que evidente que os aposentados e pensionistas, como pessoas vulneráveis e garantidoras de um tratamento diferenciado por parte do poder público, comportam uma exceção lógica ao princípio da solidariedade social, tendo em vista que já contribuíram com o sistema previdenciário ao longo de toda a vida.

O princípio da solidariedade social deveria servir justamente para proteger os cidadãos vulneráveis e não para criar um ônus sobre eles em prol unicamente da solvabilidade do sistema. ${ }^{57}$ Caso contrário, estar-se-ia diante de uma contradição lógica e ética do princípio.

O ministro Celso de Mello foi um dos julgadores vencidos na ocasião do julgamento da ADIn no 3.105, quando afirmou que o princípio da solidariedade não implica a contribuição entre ativos e inativos, mas sim um conjunto integrado de ações nas áreas da saúde, assistência e previdência

dependência, o idoso merece ser tutelado de forma diferenciada, a fim de suprir os déficits existentes, mas também capaz de valorizar os espaços de autonomia, nas áreas em que ele é competente para decidir, principalmente, acerca da sua própria vida. Esse tratamento diferenciado prima pela realização dos objetivos constitucionais atrelados à dignidade da pessoa humana (art. 1ํㅡ. III, CR/88), também determinado pela igualdade substancial (art. 3으, IV, c/c art. 5o, CR/88) e pela solidariedade (art. 3o, I, CR/88)" (p. 5).

56 BARBOZA, Heloisa Helena. Vulnerabilidade e cuidado: aspectos jurídicos. In: PEREIRA, Tânia da Silva; OLIVEIRA, Guilherme de. Cuidados e vulnerabilidade. São Paulo: Atlas, 2009. p. 109, 112 e 113. Segundo a autora: "a vulnerabilidade exige análise mais aprofundada, para que se possa proteger do melhor modo possível todas as pessoas e necessariamente, de modo especial, aqueles que têm potencializada a vulnerabilidade, ou que já se encontram vulnerados. (...) Foi o que ocorreu com o idoso. Para caracterizar a sua vulnerabilidade, enfatizou-se a sua debilitação física e mental, a cessação da produtividade, o abandono, enfim a situação indigna em que muitos se encontram. Chegou-se mesmo a assinalar sua 'invisibilidade', na medida em que não integrava um setor produtivo e economicamente ativo. (...) Há outras categorias de pessoas que têm seu estado de vulnerabilidade presumido, como os consumidores, as crianças e os idosos" (p. 109, 112 e 113).

57 O princípio da solidariedade social é muito bem definido por Cardoso de Oliveira: “É a velha forma - 'todos por um e um por todos' - que bem traduz esse aspecto da previdência social. Enquanto uns estão sadios, outros estão doentes ou inválidos; aqueles contribuem para o sustento destes, podendo mais tarde inverter-se a situação. Os moços sustentam os velhos, com sua contribuição, do mesmo modo que estes já contribuíram para que os moços pudessem criar-se e começar a trabalhar" (Citado por GONÇALVES, Nair Lemos. Auxílio-inatividade. Tese (concurso de professor titular) - Departamento de Direito do Trabalho, Faculdade de Direito, Universidade de São Paulo, 1975). 
social. ${ }^{58}$ Nesse mesmo vértice, o ministro Carlos Ayres Britto, outro julgador que teve o voto vencido no julgamento da ADIn no 3.105, também destacou tal ponto, ressaltando que a solidariedade significa, em verdade, uma parceria entre sociedade e Estado para custear a seguridade social. ${ }^{59} \mathrm{O}$ significado pragmático dado pela maioria doSTF na oportunidade é uma tentativa inglória de justificar o injustificável, pois imputa aos destinatários da solidariedade o dever de serem solidários. Resta perguntar: solidários com eles mesmos? Solidários com os servidores ativos? Solidários com o erário?

Assim, é equivocado afirmar - tendo em vista sua situação de vulnerabilidade típica dos destinatários de qualquer programa de seguridade social - que, com fulcro no denominado princípio da solidariedade, os servidores inativos devem contribuir após a sua aposentação. Nesse sentido, repise-se a respeito do chamado princípio da proibição do retrocesso social, identificado por José Joaquim Gomes Canotilho, segundo o qual os avanços sociais conquistados ao longo da evolução do direito, e retratados nos direitos sociais, não podem ser abandonados ou afastados por novas normas jurídicas. ${ }^{60}$ Para Ingo Wolfgang Sarlet, o princípio em análise consiste em "toda e qualquer forma de proteção de direitos fundamentais em face de medidas do poder público, com destaque para o legislador e o administrador, que tenham por escopo a supressão ou mesmo restrição de direitos fundamentais (sejam eles sociais, ou não)". ${ }^{61}$ Dessa forma, considera-se como um direito constitucional

58 “Ressalte-se que o princípio da solidariedade tal como invocado pela União Federal, nada mais significa do que a explicitação de um critério que já se revelava imanente ao próprio sistema de seguridade social, fundado - mesmo antes do advento das Emendas Constitucionais $\mathrm{n}^{\mathrm{o}}$ 20/98, 41/2003 e 42/2003, e no que concerne à execução do conjunto integrado de ações na área de saúde, de previdência e de assistência sociais - na exigência de financiamento global por toda a sociedade, seja mediante recursos provenientes dos orçamentos públicos, seja por intermédio de recursos oriundos da generalidade dos empregadores (inclusive o Estado) e dos trabalhadores e servidores públicos mediante o pagamento das pertinentes contribuições sociais" (STF - Ação Direta de Inconstitucionalidade 3105 DF, relator: min. ELLEN GRACIE, Data de Julgamento: 18/8/2004, Tribunal Pleno, Data de Publicação: DJ 18-02-2005 PP-00004 EMENT VOL-02180-02 PP-00123 RTJ VOL-00193-01 PP-00137 RDDT n. 140, 2007, p. 202-203. Transcrição às fls. 410 do Acórdão, voto do min. Celso de Mello).

59 "É nisso que reside a solidariedade: a sociedade e o Estado se emparceiram para desenvolver ações de seguridade social em benefício dos aposentados e pensionistas. É o que está dizendo o artigo 249. É nesse sentido que a solidariedade pode ser interpretada" (STF - Ação Direta de Inconstitucionalidade 3105 DF, relator: min. ELLEN GRACIE, Data de Julgamento: 18/8/2004, Tribunal Pleno, Data de Publicação: DJ 18-2-2005 PP-00004 EMENT VOL-02180-02 PP-00123 RTJ VOL-00193-01 PP-00137 RDDT n. 140, 2007, p. 202-203. Transcrição às fls. 410 do Acórdão, voto do min. Celso de Mello). Transcrição às fls. 411 do Acórdão, voto do min. Carlos Ayres Britto).

60 José Joaquim Gomes Canotilho, Direito constitucional e teoria da constituição, op. cit., p. 320-321.

61 SARLET, Ingo Wolfgang. Notas sobre a assim designada proibição de retrocesso social e a 
de resistência que se opõe à margem de conformação do legislador quanto à reversibilidade de leis concessivas de benefícios sociais.

Nesse passo, a respeito da incidência do princípio da proibição do retrocesso social, relevante destacar a manifestação do ministro Celso de Mello, ao invocar um pronunciamento do ministro Carlos Ayres Britto em julgamento anterior, no qual foi lembrado que a proibição do retrocesso garante o progresso das conquistas sociais. ${ }^{62}$

Com efeito, com o julgamento da ADIn no 3.105 desenhou-se um cenário de violação direta ao princípio do não retrocesso social sob o fundamento único (e equivocado) do princípio da solidariedade social, configurando, por conseguinte, um desrespeito insustentável aos direitos fundamentais, não somente dos servidores inativos - que, conforme se destacou, caracterizamse por serem indivíduos vulneráveis - , mas de todos os cidadãos que estão sujeitos à voracidade da carga tributária estatal e à ineficiência do seu regime de despesas (seja por culpa, ou mesmo por dolo, haja vista os constantes casos de corrupção que vêm sendo apurados atualmente no Brasil, demonstrando um nível elevado de tresdestinação de recursos).

Na medida em que a exação previdenciária não possui limites em uma contrapartida estatal direta e específica (à luz da interpretação que o STF deu ao princípio da solidariedade) - no caso da exação de contribuições, cujo caráter assemelha-se ao da taxa (ou imposto), em uma vinculação direta entre recolhimento e benefício - , possibilita-se a instituição das contribuições previdenciárias a bel-prazer da administração, sem nenhuma repercussão em benefícios previdenciários aos inativos, com fundamento estrito na pseudossolidariedade do sistema, em prol da sua solvabilidade, e atentandose frontalmente contra a ideia de proteção aos vulneráveis. Como se percebe, possibilita-se um verdadeiro confisco, já aludido anteriormente. ${ }^{63}$

construção de um direito constitucional comum latino-americano. Rev. TST, Brasília, v. 75, n 3, p. 116-149, jul./set. 2009. p. 121.

62 "Cabe rememorar, ainda, a propósito do postulado que veda o retrocesso social, a incisiva observação feita, na sessão de 26/05/2004, pelo eminente Ministro Carlos Britto, quando sua Excelência, cuidando da finalidade inerente às cláusulas pétreas, acentuou que estas, ' '... na Constituição de 1988, não cumprem uma função conservadora, mas, sim, impeditiva de retrocesso, ou seja, garantem o progresso...', advertindo, em conclusão de seu pensamento, que "O progresso então obtido é preciso ser salvaguardado" (STF - Ação Direta de Inconstitucionalidade 3105 DF, relator: min. ELLEN GRACIE, Data de Julgamento: 18/8/2004, Tribunal Pleno, Data de Publicação: DJ 18-2-2005 PP-00004 EMENT VOL-02180-02 PP-00123 RTJ VOL-00193-01 PP-00137 RDDT n. 140, 2007, p. 202-203. Transcrição às fls. 410 do Acórdão, voto do min. Celso de Mello).

63 Damares Medina, O Supremo Tribunal Federal e a contribuição previdenciária dos servidores inativos, passim. 


\section{As possiveis inconstitucionalidades formais na instituição de contribuição previdenciária dos servidores inativos}

Para além das inconstitucionalidades materiais inerentes a um modelo que se utiliza de contribuição previdenciária de inativos para sua sustentação financeira, há, em alguns casos, problemas também de natureza formal na instituição de tal cobrança. A União Federal, ao menos, fez publicar emenda constitucional e tal mudança seguiu os preceitos típicos do devido processo legal. Todavia, não é o que ocorre em todos os casos. A título de exemplo, no estado do Paraná a contribuição foi instituída sem emenda (somente por lei) e, ainda, seu processo de elaboração não seguiu os passos necessários para a legitimação jurídica do resultado aprovado. Por esse motivo, tornase relevante também uma reflexão sobre requisitos formais de validade de alterações normativas que imponham contribuição previdenciária dos servidores inativos e pensionistas.

\subsection{Necessidade de emenda à Constituição para a instituição da cobrança previdenciária dos servidores inativos}

Os entes federativos estaduais, ao decidir implementar a contribuição previdenciária sobre seus servidores inativos, deveriam ter, necessariamente, instituído a aludida contribuição por meio de emenda à Constituição Estadual, tendo em vista a competência de auto-organização do estado federado para regulamentar sobre seu próprio regime de previdência (art. 24, inciso XII, da Constituição) e sobre seus próprios servidores públicos.

Nesse particular, repise-se que até a edição da Emenda Constitucional no 41/2003 a cobrança dos inativos havia sido instituída no âmbito federal pela Lei $n^{-}$9.983/1999. O referido diploma legal, na sequência, foi declarado inconstitucional pelo STF no julgamento da ADIn oㅡ 2.010, e na oportunidade decidiu-se que a instituição da cobrança previdenciária deveria ter sido realizada por meio de emenda ao texto constitucional. Dessa maneira, a Emenda Constitucional no 41/2003 forneceu a necessária (e indesejável) matriz constitucional para a instituição da cobrança previdenciária dos servidores inativos, mediante a introdução, no caput do art. 40, da expressão "e inativos e dos pensionistas". ${ }^{64}$

64 O dispositivo passou então a ter a seguinte redação: “aos servidores titulares de cargos efetivos da União, dos Estados, do Distrito Federal e dos Municípios, incluídas suas autarquias e 
Tendo em vista que o próprio STF declarou a necessidade de emenda ao texto constitucional para a instituição da cobrança previdenciária, por óbvio, e considerando a autonomia do Estado-membro, a cobrança no âmbito estadual deve ser autorizada por emenda à Constituição do estado. A respeito da autonomia concedida aos estados, Fernando Dias Menezes de Almeida lembra que ela é exercida sem qualquer subordinação hierárquica ao poder central. ${ }^{65}$

Nessa senda, veja-se que, em geral, os artigos das Constituições estaduais repetem a disposição antecedente do texto federal, possuindo a seguinte redação: "aos servidores públicos titulares de cargos efetivos do Estado e dos Municípios, incluídas suas autarquias e fundações, é assegurado regime de previdência de caráter contributivo observados critérios que preservem o equilíbrio financeiro e atuarial e o disposto neste artigo". ${ }^{66}$ Denota-se, portanto, que o referido disposto faz referência apenas aos "servidores públicos titulares de cargos efetivos", omitindo-se em relação aos servidores inativos e pensionistas. Quando isso ocorrer, denota-se um descompasso entre a Constituição Federal e a Constituição estadual. Resta saber se é um descompasso legítimo ou ilegítimo.

Ao contrário do que ocorreu no Paraná, no caso do estado de São Paulo optou-se por instituir a cobrança mediante a inclusão de uma emenda à Constituição Estadual. Vale dizer, em São Paulo, a Emenda à Constituição Estadual nํำ 21, de 21 de fevereiro de 2006, possuiu o objetivo de acrescentar "alterações a fim de adequar o texto constitucional paulista às inovações trazidas por emendas constitucionais federais". O art. 126 da Constituição Estadual paulista passou a vigorar então com a seguinte redação:

fundações, é assegurado regime de previdência de caráter contributivo e solidário, mediante contribuição do respectivo ente público, dos servidores ativos $e$ inativos e dos pensionistas, observados critérios que preservem o equilíbrio financeiro e atuarial e o disposto neste artigo".

65 Em relação à autonomia concedida aos entes federativos, ensina Fernando Dias Menezes de Almeida que: "a soberania, ou seja, a qualidade de autodeterminação plena do poder, exercida sem condicionamentos de ordem interna ou externa, é exclusiva do Estado Federal. A seus integrantes - União e Estados, no mais das vezes, ou União, Estados, Distrito Federal e Municípios, como no caso brasileiro - é atribuída autonomia, que é também poder de autodeterminação, demarcado, porém, por um círculo de competências traçado pelo poder soberano, que garante aos entes autônomos - pensando-se em autonomia no seu mais alto grau - capacidade de auto-organização, autogoverno, autolegislação e autoadministração, exercida sem subordinação hierárquica dos poderes periféricos ao poder central" (ALMEIDA, Fernando Dias Menezes de. Comentários ao artigo 18, inciso XXIII. In: J. J. Gomes Canotilho, Gilmar Ferreira Mendes, Ingo Wolfgang Sarlet e Lenio Luiz Streck, Comentários à Constituição do Brasil, op. cit., p. 700).

66 Como exemplo foi citado o art. 35, caput, da Constituição do estado do Paraná. 
aos servidores titulares de cargos efetivos do Estado, incluídas suas autarquias e fundações, é assegurado regime de previdência de caráter contributivo e solidário, mediante contribuição do respectivo ente público, dos servidores ativos e inativos e dos pensionistas, observados critérios que preservem o equilíbrio financeiro e atuarial e o disposto neste artigo.

Portanto, o estado de São Paulo optou expressamente pela instituição da contribuição previdenciária sobre os servidores inativos, após realizar a devida e necessária inclusão em sede de texto constitucional estadual.

Por outro lado, no estado do Paraná, que está sendo utilizado neste texto como exemplo, não houve a inclusão dos servidores inativos e pensionistas como contribuintes no texto da Constituição Estadual. Isto é, não houve a necessária e devida reforma à Constituição do estado, a fim de que a cobrança previdenciária fosse regularmente (do ponto de vista formal) instituída. Assim, considerando que não foi respeitado um requisito obrigatório para a alteração do modelo, e tendo em vista que a matéria está acobertada na competência do ente estadual de auto-organização (nos termos do art. 24, inciso XII, da Constituição Federal), deflagrou-se um cenário de inconstitucionalidade formal. Segundo Clèmerson Merlin Clève, instaura-se o cenário de uma inconstitucionalidade formal quando o procedimento de elaboração da lei é diverso daquele fixado na Constituição (inconstitucionalidade formal propriamente dita) ${ }^{67}$ Rodrigo Padilha, por seu turno, refere-se a tal hipótese como "inconstitucionalidade formal por violação de pressuposto objetivo do ato normativo". Para o aludido autor, essa hipótese ocorre quando o vício atinge pressuposto obrigatório para a realização do ato. ${ }^{68}$

Cumpre lembrar, nesse ponto, a indiscutível competência estadual para auto-organização da matéria, à luz do que preceitua o art. 24, inciso XII, do texto constitucional, o que apenas reforça a necessidade de emenda para a instituição da contribuição em comento. Fernando Dias Menezes de Almeida, ao comentar o dispositivo em tela, aduz que a União Federal possui "competência para editar apenas normas gerais, cabendo a Estados e Distrito Federal a legislação suplementar, nos termos dos $\S \S 1^{\circ}$ e 2 o do art. 24".

67 CLÈVE, Clèmerson Merlin. A fiscalização abstrata da constitucionalidade no direito brasileiro. 2. ed. São Paulo: Revista dos Tribunais, 2000. p. 39.

68 PADILHA, Rodrigo. Direito constitucional. Rio de Janeiro: Forense, São Paulo, 2013. p. 108. 
O autor, ainda, evidencia que, no caso da legislação suplementar, os estadosmembros possuem competência para legislar sobre o tema de acordo com suas particularidades. ${ }^{69}$

Rememore-se, outrossim, que no ano de 2005 o estado do Paraná e a ParanáPrevidência propuseram uma ação ordinária em face da União Federal, perante a Justiça Federal do estado do Paraná, pleiteando a inconstitucionalidade do art. 9o, caput e incisos, da Lei no 9.1717/1998, do Decreto no 3.788/2001 e da Portaria do Ministério da Previdência e Assistência Social $\mathrm{n}$ o 172/2005, por afronta a autonomia do ente federativo e seu gestor previdenciário. ${ }^{70}$ Vale dizer, alegou-se que a União Federal, naquele caso, teria invadido a gestão estadual em relação ao seu regime próprio de previdência, ao aplicar sanções ao estado do Paraná com base na Lei no 9.717/1998, por não ter instituído a cobrança previdenciária sobre os servidores inativos. ${ }^{71}$

Ao conceder a medida liminar aos autores, reconheceu-se, portanto, na oportunidade, que o ente estadual possui indiscutível competência para dispor

69 Fernando Dias Menezes de Almeida, Comentários ao artigo 22, inciso XXIII, op. cit., p. 745. Complementa o autor: "o que se pode sugerir é o reconhecimento da competência da União de legislar integralmente sobre tudo o que se inclui na seguridade social, aplicando-se no âmbito da Administração Federal, tanto as normas gerais, quanto as normas específicas que forem elaboradas. Já nos planos estadual e distrital, prevaleceriam as normas gerais produzidas pela União, cabendo aos demais entes federados a complementação legislativa, para atender às suas particularidades - o que se resume, ao que parece, no caso da previdência social, aos respectivos servidores públicos" (p. 745).

70 STF mantém isenção do desconto de inativos no PR. Gazeta do Povo. Disponível em: <www. gazetadopovo.com.br/vida-publica/stf-mantem-isencao-do-desconto-de-inativos-no-prapicczxzse5nxnzofiioue5vy>. Acesso em: 20 abr. 2015.

71 No referido caso, o Supremo Tribunal Federal, ao apreciar a liminar pleiteada pelos estado do Paraná e pela ParanáPrevidência, entendeu, através do voto do seu ministro relator Marco Aurélio, o seguinte: "constato, neste exame preliminar, que se adentrou não o campo do simples estabelecimento de normas gerais. Atribuem-se a ente da Administração Central, ao Ministério da Previdência e Assistência Social, atividades administrativas em órgãos da Previdência Social dos Estados, do Distrito Federal, dos Municípios e dos fundos a que se refere o artigo $6^{\circ}$ da citada lei. A tanto equivale a previsão de que se compete ao Ministério da Previdência e Assistência Social orientar, supervisionar e acompanhar as práticas relativas à previdência social dos servidores públicos das unidades da Federação. Mais do que isso, mediante o preceito do artigo 7ํㅡ, dispôs-se sobre sanções diante do descumprimento das normas - que se pretende enquadradas como gerais. Deparo, assim, com quadro normativo federal que, à primeira vista, denota o extravasamento dos limites constitucionais, da autonomia própria, em se tratando de uma Federação. Uma coisa o estabelecimento de normas gerais a serem observadas pelos Estados membros. Algo diverso é, a pretexto da edição dessas normas, a ingerência na administração dos Estados, quer sob o ângulo direto, quer sob o indireto, por meio de autarquias. Vale frisar que não prospera o paralelo feito entre a legislação envolvida na espécie e a denominada Lei de Responsabilidade Fiscal, editada a partir de previsão expressa contida no artigo 169 da Constituição Federal, impondo limites a serem atendidos pelos Estados, Distrito Federal e Municípios" (ACO 830-TAR/PR, Tribunal Pleno, DJ 15.3.2007). 
acerca do seu próprio regime de previdência, nos termos do art. 24, inciso XII, da Constituição, limitando-se a União à expedição de normas gerais. Tratase de manifesta matéria abrangida no exercício de auto-organização do ente estadual (impedindo-se, assim, a União Federal de aplicar sanções com base na Lei no 9.717/1998).

E, em sendo competência estadual dispor acerca do seu próprio regime de previdência (além de ser competência também do estado-membro regulamentar acerca do seu próprio regime de servidores), mais do que óbvio que se exigia a regulamentação da matéria via emenda à Constituição estadual. Dessa forma, os estados federados não podem instituir a cobrança previdenciária dos inativos sem a correspondente emenda à Constituição estadual (na realidade, não podem de jeito algum, considerando sua inconstitucionalidade material, mas sem emenda a situação torna-se ainda mais radicalmente inconstitucional - agora também por motivos formais).

\subsection{Violação ao devido processo legislativo}

Outro problema que pode ser observado na prática políticoadministrativa brasileira é a supressão do devido processo legislativo. E tal situação pode ser observada comumente no Congresso Nacional. Todavia, o estado do Paraná continua sendo um exemplo profícuo de atuação irregular nessa seara. Mesmo que não fosse necessária uma emenda à Constituição estadual para a instituição da cobrança sobre os inativos, tal cobrança (por lei) é inconstitucional ainda em relação ao aspecto formal em caso de existir qualquer violação ao devido processo legislativo. Vale dizer, a instituição da cobrança previdenciária sobre os inativos por meio de legislação ordinária estadual já é, por si só, uma flagrante inconstitucionalidade; entretanto, como será exposto na sequência, mesmo que se admitisse a inclusão sem emenda à Constituição do estado, assim ainda o projeto de lei que originou a cobrança é eivado de patente inconstitucionalidade formal se não respeita os ditames procedimentais exigidos constitucionalmente.

Nesse vértice, Luís Roberto Barroso lembra que haverá a configuração de inconstitucionalidade formal propriamente dita se uma espécie normativa for instituída sem a observância do processo legislativo próprio. ${ }^{72} \mathrm{E}$ foi exatamente

72 BARROSO, Luís Roberto. O controle de constitucionalidade no direito brasileiro. 3. ed. São Paulo: Saraiva, 2008. p. 27. 
o que ocorreu no caso da instituição da cobrança previdenciária sobre os inativos no âmbito do estado do Paraná: um cenário de inconstitucionali-

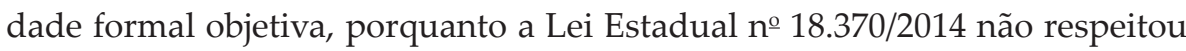
um elemento fundamental do devido processo legislativo constitucional: a formação das comissões. ${ }^{73} \mathrm{O}$ que se viu, assim, foi o comumente chamado "tratoraço", com a transformação dos debates parlamentares e sessões legislativas em meros disfarces.

$\mathrm{O}$ art. 58 da Constituição dispõe que "o Congresso Nacional e suas Casas terão comissões permanentes e temporárias, constituídas na forma e com as atribuições previstas no respectivo regimento ou no ato de que resultar sua criação". Já o art. 62, da Constituição do estado do Paraná, prescreve que: "a Assembleia Legislativa terá comissões permanentes e temporárias, constituídas na forma e com as atribuições previstas nesta Constituição, no Regimento Interno, ou no ato de que resultar a sua criação". Portanto, denotase que o Poder Legislativo deve possuir comissões, em respeito ao devido processo legislativo, cujas atribuições, conforme preceituam os referidos dispositivos, devem ser previstas no respectivo regimento interno. Nesse sentido, lembra Anna Candida da Cunha Ferraz que "nenhuma decisão relevante para os destinos do país, a ser tomada pelo Congresso Nacional, deve ser definida sem prévio exame de comissões especializadas". ${ }^{74}$ No mesmo sentido é a opinião de José Afonso da Silva:

de fato, entre nós, apresentado o projeto, este é remetido às comissões competentes para opinar e só entrará em Ordem do Dia para discussão desde que tenham parecer das comissões a que foi distribuída, pois em princípio, nenhuma proposição, nenhum projeto, será submetido a discussão e votação sem parecer escrito da comissão competente. ${ }^{75}$

73 CASSEB, Paulo Adib. Processo legislativo: atuação das comissões permanentes e temporárias. São Paulo: RT, 2008. p. 240. Para o referido autor: “a Constituição brasileira de 1988 revelouse generosa no que tange à previsão da atuação de comissões parlamentares, tendo em vista que em diversos momentos faz referência aos trabalhos desses órgãos internos do Congresso Nacional e de suas Casas, por vezes apresentando uma disciplina razoavelmente detalhada" (p. 240).

74 FERRAZ, Anna Candida da Cunha. Comentários ao artigo 58. In: J. J. Gomes Canotilho, Gilmar Ferreira Mendes, Ingo Wolfgang Sarlet e Lenio Luiz Streck, Comentários à Constituição do Brasil, op. cit., p. 1091. Para a autora: "com certeza, errará menos o Poder Legislativo se estiver devidamente informado sobre os assuntos a respeito dos quais deva decidir. Isso significa dizer que a distribuição e organização das comissões é matéria relevante e deve obedecer a critérios funcionais que lhe permitam, de modo efetivo, auxiliar nas tarefas exercidas pelo Legislativo, particularmente na de legislar". (p. 1091).

75 SILVA, José Afonso. Processo constitucional de formação das leis. 2. ed. São Paulo: Malheiros, 2006. p. 111. 
Porém, não foi o que se viu no processo legislativo que ocasionou a Lei no 18.370/2014. Com efeito, o Projeto de Lei no 511/2014, após passar pela Comissão de Constituição e Justiça, deveria ter sido encaminhado à Comissão de Finanças e, na sequência, para a Comissão de Orçamento. Os pareceres dessas comissões possuíam enorme relevância no caso, haja vista que a justificativa do projeto era a "manutenção do equilíbrio financeiro e atuarial dos Fundos de Natureza Previdenciária". O que se viu, entretanto, foi a transformação do Plenário da Assembleia Legislativa do Paraná (Alep) em Comissão Geral para votação do Projeto de Lei no 511/2014. Conforme dispõe o Regimento Interno da Câmara dos Deputados, o Plenário pode até ser transformado em Comissão Geral para debater matérias relevantes ou receber autoridades, mas nunca para votar projetos de lei em definitivo. ${ }^{76}$ No mesmo sentido, aduz a redação do Regimento Interno da Assembleia Legislativa do Paraná em seu revogado art. $107 .{ }^{77}$

Como se pode claramente notar, é manifestamente inconstitucional a transformação do Plenário da Assembleia em Comissão Geral para votação de projetos de lei, com supressão da participação das comissões temáticas permanentes no processo legislativo, como a Comissão de Finanças e a Comissão de Orçamento. E a prova disso é que, no dia 10 de março de 2015, os deputados estaduais do Paraná, “com 51 votos favoráveis e nenhum voto contrário", revogaram o art. 107 do Regimento Interno da Assembleia Legislativa do Paraná, alusivo à malfadada Comissão Geral. Tratando do

76 “Art. 91. A sessão plenária da Câmara será transformada em Comissão Geral, sob a direção de seu Presidente, para: I - debate de matéria relevante, por proposta conjunta dos Líderes, ou a requerimento de um terço da totalidade dos membros da Câmara; II - discussão de projeto de lei de iniciativa popular, desde que presente o orador que irá defendê-lo; III comparecimento de Ministro de Estado. §1ํㅡ A Comissão Geral convocada com fundamento no inciso I do caput terá por finalidade fomentar o debate sobre matéria relevante por meio da oitiva de autoridades, especialistas com notório conhecimento sobre o tema, membros de entidade da sociedade civil, e demais pessoas com experiência e autoridade na matéria, limitados a, no máximo, 2 (dois) convidados indicados por Partido ou Bloco, cuja lista deverá ser divulgada pela Mesa com, no mínimo, 24 (vinte e quatro) horas de antecedência" (BRASIL. Congresso Nacional. Câmara dos Deputados. Regimento interno da Câmara dos Deputados. 15. ed. Brasília: Câmara dos Deputados, Edições Câmara, 2015. p. 44).

77 Art. 107. A Sessão Plenária da Assembleia será transformada em Comissão Geral, por proposta conjunta de Líderes, ou por um terço dos membros da Assembleia, sob a direção de seu Presidente, para: I - debate de matéria relevante; II - estudo de qualquer assunto, ou outro fim determinado; III - discussão de projeto de lei de iniciativa popular, desde que presente o orador que irá defendê-lo; IV - comparecimento de Secretário de Estado. §1ํㅡ A Assembleia será constituída em Comissão Geral, com a aprovação da maioria absoluta dos votos" (PARANÁ. Regimento Interno da Assembleia Legislativa do Estado do Paraná. 3a Sessão Legislativa. 17ª Legislatura. Curitiba: Assembleia Legislativa do Estado do Paraná, 2013. p. 88). 
procedimento legislativo, bem esclarece José Afonso da Silva: “o procedimento, qualquer que seja, está subordinado à ocorrência de certas condições para ser admitido. A inocorrência de qualquer dessas condições poderá gerar uma irregularidade procedimental que poderá influir na validade da lei em face das normas constitucionais" ${ }^{78}$

\section{Conclusão}

O presente trabalho parte da hipótese de existência de fortes inconstitucionalidades materiais quando da instituição da cobrança previdenciária sobre servidores inativos e pensionistas. Propôs-se, assim, que a instituição da cobrança pela Emenda Constitucional no 41/2003 agride direitos fundamentais estabelecidos como cláusula pétrea. Como ensinava o insigne Rui Barbosa: "o aposentado, o jubilado, o reformado, o pensionista do Tesouro são credores da Nação, por títulos definitivos, perenes e irretratáveis". ${ }^{79}$

Em primeiro lugar, entende-se afrontadas as garantias do ato jurídico perfeito e do direito adquirido contra a Emenda Constitucional no 41/2003. À luz do que preceitua o art. 5ํ, inciso XXXVI, da Constituição, o termo "lei" também deve ser estendido às emendas constitucionais, isto é, elas também devem respeitar a garantia do ato jurídico perfeito e do direito adquirido. E, nesse sentido, parece merecer uma forte crítica a posição do STF atualmente vigente sobre o assunto.

Mereceu destaque, também, nesse tocante, o princípio da confiança e da boa-fé. Os cidadãos, motivados pela convicção da boa-fé e confiando no agir estatal, não merecem ser vilipendiados em seus direitos por uma desleal ação do poder público que, desacreditando o princípio da segurança das relações jurídicas, pretende impor-lhes uma obrigação inconstitucional. Ademais, configura-se evidente um cenário de confisco em relação ao caráter alimentar das prestações previdenciárias, bem como torna-se patente a existência de

78 Joé Afonso da Silva, Processo constitucional de formação das leis, op. cit., p. 261.

79 “O aposentado, o jubilado, o reformado, o pensionista do Tesouro são credores da Nação, por títulos definitivos, perenes e irretratáveis. Sob um regime, que afiança os direitos adquiridos, santifica os contratos, submete ao cânon da sua inviolabilidade o Poder Público e, em garantia deles, adstringe as leis à norma tutelar da irretroatividade, não há consideração de natureza alguma, juridicamente aceitável, moralmente honesta, socialmente digna, logicamente sensata, pela qual se possa amortizar o Estado a não honrar a dívida, que com esses credores contraiu, obrigações que para com eles firmou". BARBOSA, Rui. Obras seletas, Título X: Trabalhos jurídicos. Rio de Janeiro: Fundação Biblioteca Nacional, 1956. p. 10. 
tributação sem causa quando o poder público institui uma cobrança sem a respectiva contraprestação; além da ofensa direta ao princípio do ne bis in idem.

Por derradeiro, destacou-se, ainda, a violação ao princípio da proibição do retrocesso social e a inversão da lógica da solidariedade previdenciária por meio da criação de um ônus sobre os vulneráveis. Com efeito, com o julgamento da ADIn no 3.105 instaurou-se uma situação de afronta direta ao princípio do não retrocesso social sob o fundamento único (e equivocado) do princípio da solidariedade, configurando, por consequência, outro desrespeito aos direitos fundamentais estabelecidos constitucionalmente. Ademais, podem ser também caracterizadas inconstitucionalidades formais no caso de tal contribuição não ter sido estabelecida por emenda à Constituição Estadual, no caso dos inativos e pensionistas estaduais. Ao instituir a cobrança sem a necessária emenda à Constituição do estado, exigida diante da competência estadual de auto-organização para dispor em relação ao seu próprio regime de previdência, incorre-se em flagrante inconstitucionalidade quanto à forma. Por outro lado, a cobrança também será formalmente inconstitucional no caso de denotar-se violação ao devido procedimento legislativo pela Assembleia Legislativa dos estados.

Enfim, conclui-se com as simbólicas palavras da professora Eneida Desiree Salgado: “O aprimoramento dos institutos deve ser feito no espaço permitido pela Constituição. Ou por intermédio de mudanças que recuperem seu sentido. Jamais desvirtuando seu espírito ou desconsiderando sua configuração como produto de uma luta democrática" ${ }^{80}$

\section{Referências}

ALMEIDA, Fernando Dias Menezes de. Comentários ao artigo 18, inciso XXIII. In: CANOTILHO, José Joaquim Gomes; MENDES, Gilmar Ferreira; SARLET, Ingo Wolfgang; STRECK, Lenio Luiz (Coords.). Comentários à Constituição do Brasil. São Paulo: Saraiva; Almedina, 2013.

. Comentários ao artigo 22, inciso XXIII. In: CANOTILHO, José Joaquim Gomes; MENDES, Gilmar Ferreira; SARLET, Ingo Wolfgang; STRECK,

80 SALGADO, Eneida Desiree. Constituição e democracia: tijolo por tijolo em um desenho (quase) lógico. Belo Horizonte: Fórum, 2007. p. 260. 
Lenio Luiz (Coords.). Comentários à Constituição do Brasil. São Paulo: Saraiva; Almedina, 2013.

ATALIBA, Geraldo. Hipótese de incidência tributária. 5. ed. São Paulo: Malheiros, 1993.

BACELLAR FILHO, Romeu Felipe. A estabilidade do ato administrativo criador de direitos à luz dos princípios da moralidade, da segurança jurídica e da boa-fé. AEC - Biblioteca Digital Revista de Direito Administrativo $\mathcal{E}$ Constitucional, Belo Horizonte, a. 10, n. 40, abr./jun. 2010. Disponível em: $<$ www.editoraforum.com.br/bid/bidConteudoShow.aspx?idConteudo= 67732>.Acesso em: 7 jul. 2010.

BARBOSA, Rui. Obras seletas. Título X: Trabalhos jurídicos. Rio de Janeiro: Fundação Biblioteca Nacional, 1956.

BARBOZA, Heloisa Helena. Vulnerabilidade e cuidado: aspectos jurídicos. In: PEREIRA, Tânia da Silva; OLIVEIRA, Guilherme de. Cuidados e vulnerabilidade. São Paulo: Atlas, 2009.

BARROSO, Luís Roberto. Curso de direito constitucional contemporâneo. 3. ed. São Paulo: Saraiva, 2011.

. O controle de constitucionalidade no direito brasileiro. 3. ed. São Paulo: Saraiva, 2008.

BITTENCOURT, Mario Diney Corrêa. Aposentadoria de servidor público - ato jurídico perfeito - direito adquirido - irretroatividade das normas. Revista dos Institutos dos Advogados do Paraná, n. 26, 1996.

BRITTO, Carlos Ayres; PONTES FILHO, Valmir. Direito adquirido contra as emendas constitucionais. In: MELLO, Celso Bandeira de (Org.). Estudos em homenagem a Geraldo Ataliba: direito administrativo e constitucional. São Paulo: Malheiros, 1997.

CANOTILHO, José Joaquim Gomes. Direito constitucional e teoria da Constituição. Coimbra: Almedina, 2000.

CASSEB, Paulo Adib. Processo legislativo: atuação das comissões permanentes e temporárias. São Paulo: RT, 2008.

CARRAZA, Roque Antônio. Curso de direito constitucional tributário. 10. ed. São Paulo: Malheiros, 1995. 
CAVALIERI FILHO, Sérgio. Programa de responsabilidade civil. 8. ed. São Paulo: Atlas, 2008.

CLÈVE, Clèmerson Merlin. A fiscalização abstrata da constitucionalidade no direito brasileiro. 2. ed. São Paulo: Revista dos Tribunais, 2000.

. Temas de direito constitucional. 2. ed. Belo Horizonte: Fórum, 2014.

COÊLHO, Sacha Calmon Navarra. Direito tributário contemporâneo. São Paulo: Revista dos Tribunais, 1997.

COSTA, Regina Helena. Curso de direito tributário: Constituição e Código Tributário Nacional. 4. ed. São Paulo: Saraiva, 2014.

_.. Princípio da capacidade contributiva. 4. ed. São Paulo: Malheiros, 2012.

DI PIETRO, Maria Sylvia Zanella. Direito administrativo. 17. ed. São Paulo: Atlas, 2004.

FERRARI, Regina Maria Macedo Nery. Direito constitucional. São Paulo: Revista dos Tribunais, 2011.

- O ato jurídico perfeito e a segurança jurídica no controle de constitucionalidade. In:__. Constituição e segurança jurídica: direito adquirido, ato jurídico perfeito e coisa julgada. Estudos em homenagem a José Paulo Sepúlveda Pertence. Belo Horizonte: Fórum, 2004.

FERRAZ, Anna Candida da Cunha. Comentários ao artigo 58. In: CANOTILHO, J. J. Gomes; MENDES, Gilmar F.; SARLET, Ingo W.; STRECK, Lenio L. (Coord.). Comentários à Constituição do Brasil. São Paulo: Saraiva; Almedina, 2013.

FREITAS, Juarez. O controle dos atos administrativos e os princípios fundamentais. São Paulo: Malheiros, 2013.

GABARDO, Emerson. Interesse público e subsidiariedade: o Estado e a sociedade civil para além do bem e do mal. Belo Horizonte: Fórum, 2009.

HACHEM, Daniel Wunder. Princípio constitucional da supremacia do interesse público. Belo Horizonte: Fórum, 2011.

MARTINEZ, Wladimir Novaes. Curso de direito previdenciário. Tomo I Noções de direito previdenciário. São Paulo: LTR, 1997.

MEDINA, Damares. O Supremo Tribunal Federal e a contribuição previdenciária dos servidores inativos. Jusbrasil. Disponível em: <jus.com.br/ 
artigos/11797/o-supremo-tribunal-federal-e-a-contribuicao-previdenciariados-servidores-inativos>. Acesso em: 19 abr. 2015.

MENDES, Gilmar Ferreira. Comentários ao artigo 5o, inciso XXXVI. In: CANOTILHO, José Joaquim Gomes; MENDES, Gilmar Ferreira; SARLET, Ingo Wolfgang.; STRECK, Lenio Luiz (Coord.). Comentários à Constituição do Brasil. São Paulo: Saraiva/Almedina, 2013.

; BRANCO, Paulo Gustavo Gonet. Curso de direito constitucional. São Paulo: Saraiva, 2012.

MOREIRA, Egon Bockmann. O princípio da legalidade, a lei e o direito. In: MARRARA, Thiago (Org.). Princípios de direito administrativo: legalidade, segurança jurídica, impessoalidade, publicidade, motivação, eficiência, moralidade, razoabilidade, interesse público. São Paulo: Atlas, 2012.

PACHECO FILHO, Calino; WINCKLER, Carlos Roberto. Reforma na previdência: o ajuste no serviço público. Indic. Econ. FEE, Porto Alegre, v. 32, n. 4, p. 221-248, mar. 2005.

PADILHA, Rodrigo. Direito constitucional. Rio de Janeiro: Forense, 2013.

POSNER, Richard A. Para além do direito. São Paulo: WMF Martins Fontes, 2009.

RAMOS, Elival da Silva. Ativismo judicial: parâmetros dogmáticos. São Paulo: Saraiva, 2010.

RIBEIRO, Leonardo Coelho; FREITAS, Rafael Véras de. Manutenção do ambiente negocial entre o público e o privado e desenvolvimento nacional: o impacto das modulações regulatórias nos contratos da Administração e o dever de coerência administrativa. In. CÔRREA, André Rodrigues; PINTO JÚNIOR, Mario Engler (Org.). Cumprimento de contratos e razão de Estado. São Paulo: Saraiva, 2013.

ROCHA, Daniel Machado da. Comentários ao artigo 40. In: CANOTILHO, José Joaquim Gomes; MENDES, Gilmar Ferreira; SARLET, Ingo Wolfgang; STRECK, Lenio Luiz (Coord.). Comentários à Constituição do Brasil. São Paulo: Saraiva; Almedina, 2013.

RODRÍGUEZ-ARANA MUÑOZ, Jaime. Direito fundamental à boa administração pública. Belo Horizonte: Fórum, 2012.

SALGADO, Eneida Desiree. Constituição e democracia: tijolo por tijolo em um desenho (quase) lógico. Belo Horizonte: Fórum, 2007. 
SARLET, Ingo Wolfgang; BRANDÃO, Rodrigo. Comentários ao artigo 60. In: CANOTILHO, José Joaquim Gomes; MENDES, Gilmar Ferreira; SARLET, Ingo Wolfgang; STRECK, Lenio L. (Coords.). Comentários à Constituição do Brasil. São Paulo: Saraiva; Almedina, 2013.

- Notas sobre a assim designada proibição de retrocesso social e a construção de um direito constitucional comum latino-americano. Rev. TST, Brasília, v. 75, n. 3, p. 116-149, jul./set. 2009.

SILVA, José Afonso. Curso de direito constitucional positivo. São Paulo: Malheiros, 2013.

_. Processo constitucional de formação das leis. 2. ed. São Paulo: Malheiros, 2006.

STRECK, Lenio Luiz. Hermenêutica e princípios da interpretação constitucional. In: CANOTILHO, José Joaquim Gomes; MENDES, Gilmar Ferreira; SARLET, Ingo Wolfgang; STRECK, Lenio Luiz (Coord.). Comentários à Constituição do Brasil. São Paulo: Saraiva; Almedina, 2013.

TAVARES, André Ramos. Curso de direito constitucional. São Paulo: Saraiva, 2008.

TEIXEIRA, Ana Carolina Brochado; RIBEIRO, Gustavo Pereira Leite. Procurador para cuidados de saúde do idoso. In: PEREIRA, Tânia da Silva; OLIVEIRA, Guilherme de. Cuidados e vulnerabilidade. Paulo: Atlas, 2009.

TORRES, Heleno. Comentários ao artigo 150, inciso IV. In: CANOTILHO, José Joaquim Gomes; MENDES, Gilmar Ferreira; SARLET, Ingo Wolfgang; STRECK, Lenio Luiz (Coord.). Comentários à Constituição do Brasil. São Paulo: Saraiva; Almedina, 2013. 